\title{
THE ASSOCIATION BETWEEN GENDER-DIVERSE COMPENSATION COMMITTEES AND CEO COMPENSATION
}

\begin{abstract}
We examine the association between gender-diverse compensation committees and CEO pay and find that CEO compensation levels are negatively associated with gender-diversity of the compensation committee, but not gender-diversity of the board. Furthermore, we find that excess CEO compensation is negatively related to subsequent return on assets for firms with an all-male compensation committee but not for firms with a gender-diverse compensation committee. These results suggest that CEOs do receive some level of excess compensation which can be mitigated by having one or more females on the compensation committee.
\end{abstract}

Keywords: Gender-diversity, compensation committee, CEO compensation 


\section{INTRODUCTION}

There is a global trend by policy makers and regulators to increase women on boards. Some European countries including Norway, Spain and France have sought to implement gender quotas, others use networking and mentoring programmes to quicken women's rise to the top. ${ }^{1}$ The academic community has responded to this global trend by providing evidence on the differences between male and female directors, and/or the effect of gender-diversity on different corporate decisions. We build on this literature by investigating the economic consequences of gender-diversity in the context of CEO compensation. Specifically, our objectives are to provide evidence on: (i) the association between gender-diverse compensation committees and levels of CEO compensation, and (ii) the effect of genderdiverse compensation committees on the association between firm performance and 'excess' CEO compensation. ${ }^{2}$

This study contributes to the current debate on executive compensation levels and structures. Executive compensation levels have undergone renewed scrutiny following the global financial crisis and are criticised for encouraging excessive risk taking. ${ }^{3}$ As a result, legislation has been proposed or enacted which restricts the level and proportion of the components of executive pay. ${ }^{4}$ This study contributes to these professional debates by providing evidence on the association between firms with a gender-diverse compensation

\footnotetext{
${ }^{1}$ Norway maintains a mandatory gender quota of $40 \%$, Spain of $40 \%$ by 2015 , and France is to introduce $50 \%$ by 2015 . More recently, the European commission is seeking to implement a $40 \%$ female-quota for company boards across Europe, which is being opposed by eight countries including Britain, the Czech Republic, Hungary and Malta (Traynor 2012).

2 'Excess' compensation is compensation above what can be explained by economic determinants (e.g. Core, Guay and Larcker 2008, and Core, Holthausen and Larcker 1999).

${ }^{3}$ For example see Cuomo (2009) and Parsons and Puzzanghera (2009).

4 See Weisman and Lublin (2009) and Schuman (2010) for some U.S. examples and Murphy (2010) for proposed changes in Europe. There is also legislation introduced in March 2013 in Switzerland which mandates that CEOs' incentive payments cannot be greater than a marked percent of their base compensation. And more recently, Say on Pay legislation is being implemented in numerous countries (see for example, Burns and Minnick (2013), Correa and Lel (2013), Cunat et al. (2013), and Kimbro and Xu (2013)).
} 
committee and CEO compensation. Our results suggest that gender-diverse compensation committees may be one possible way of reducing excess CEO compensation levels.

To date, we are not aware of any direct empirical evidence on the association between CEO compensation and gender-diversity of the compensation committee. However, there are a number of related studies which focus on some aspects of CEO compensation levels or excess compensation, and some characteristics of the compensation committee and/or board. For example, Daily et al. (1998) examine the governance characteristics of compensation committees and report evidence that boards are not captured by CEOs. Similarly, Anderson and Bizjak (2003) provide evidence that there is no association between CEO pay structures or levels and compensation committee independence. Core et al. (1999) document that CEOs who are also chairman of the board receive excess compensation, and Adams and Ferreira (2009) find that board level gender-diversity is unrelated to both total CEO compensation and the percentage of CEO pay that is incentive based.

We provide evidence on the association between gender-diversity of the compensation committee and CEO compensation. In this study we focus on gender-diversity of the compensation committee rather than the board because it is this board subcommittee which negotiates and determines executive compensation levels. Second, we expect that gender diversity of the compensation committee may be related to CEO compensation levels based of recent evidence which documents positive consequences arising from board genderdiversity. For example, firms with gender-diverse boards have better stock price informativeness (Gul et al. 2011), higher earnings quality (Srinidhi et al. 2011), make better merger and acquisition (M\&A) decisions (Levi et al. 2014), and have greater corporate social 
performance or responsibility (e.g. Bear, Rahman and Post 2010; Boulouta 2013; Zhang, Zhu and Ding 2013). ${ }^{5}$

A possible explanation for the positive effect of board gender diversity is that it results in different group dynamics during meetings. For example, Huse and Solberg (2006) document that both women and men need to understand the power game played by board members, form alliances, spend time on preparation, and be present at the decision making avenues. Their study shows that these dynamics are not gender neutral. Adams and Funk (2012) in a recent study found that whilst female directors are more benevolent and less power oriented, they are less traditional and security-oriented than their male counterparts.

An alternative plausible explanation for the above evidence on gender-diverse boards is that women are more likely to have a greater input into the board process by attending more meetings, by being more likely to join subcommittees of the board, and even influencing men's board attendance (Adams and Ferreira 2009). Finally, Konrad et al. (2008) find that women ask tougher questions and note numerous instances where female directors are alone in questioning the CEO's compensation or voting no on compensation issues. Therefore, we expect that during meetings of the compensation committee female directors raise questions that male directors are unwilling to ask, thus prompting greater discussion and analysis of the compensation contract.

While there is no qualitative evidence as to why women ask the 'tougher' questions, a possible explanation is that female directors feel more secure in their position because they have had to work harder to attain their board seat (Eagly and Carli 2003), or because the firm

5 Krishnan and Parsons (2008) also document a positive relation between gender-diversity of senior management and earnings quality. However, the relation between gender-diversity and firm performance remains mixed (e.g. Campbell and Minguez-Vera 2008; Adams and Ferreira 2009; Joecks, Pull and Vetter 2013; Chapple and Humphrey 2014). 
faces pressure from stakeholders and regulators to maintain one or more female directors on the board. Therefore, female directors may not feel indebted to the CEO and are less likely to be captured. For example, Konrad et al. (2008, p160) quote a male CEO from a Fortune 1000 firm stating "Men - CEOs - are still putting on boards those they know and are comfortable with... packing it with their friends... women are perceived as more outsiders. They are not the typical CEO playing golf on a weekend and socializing together outside the office". Taking the above considerations together we expect that gender-diverse compensation committees are less likely to be captured by the CEO and hence are less likely to pay excessive compensation. Hence, our first prediction is that there is a negative association between gender-diversity of the compensation committee and levels of CEO compensation.

We are also not aware of any analytical or empirical research which provides a direct framework or evidence on the association between gender-diverse compensation committees, excess CEO compensation and firm performance. However, there are a number of important empirical papers which provide insights into related issues. For example, the empirical evidence of Core et al. (1999) suggests that CEO compensation contracts are 'suboptimal' with respect to the corporate governance characteristics of the firm, and that CEOs are able to obtain excess compensation. They also find that excess compensation (that is compensation beyond what the economic characteristics of the firm would predict) is negatively related to firm performance. Larcker et al. (2007) groups corporate governance into several general categories and finds that some board characteristics (e.g. having a lead director) are positively associated with future excess stock market performance (however, their board characteristics do not include gender-diversity). Sun et al. (2009) also find a positive association between an interaction term based on a corporate governance score with equity-based compensation and firm performance. However, their corporate governance score does not include a gender- 
diversity measure and their evidence relates to compensation levels not to excess compensation.

If gender-diverse compensation committees are less prone to being captured by CEOs (for the reasons discussed previously) and thus associated with lower levels of excess CEO compensation, our second prediction is that excess CEO compensation in these firms has no performance consequences because CEOs are appropriately incentivised.

\section{RESEARCH DESIGN}

\subsection{Research method for testing the association between compensation level and gender- diversity of the compensation committee.}

To demonstrate the importance of focusing on the characteristics of board subcommittees rather than the board itself, we first test the association between board genderdiversity and CEO compensation levels similar to Adams and Ferreira (2009). Second, we test the association between compensation committee gender-diversity and CEO compensation levels. The following ordinary least-squares model (OLS) is estimated based on our total sample:

$$
\begin{aligned}
& \operatorname{Comp}_{i t}=\beta_{0}+\beta_{1} \text { Femdir }\left(\mathrm{F}_{-} \text {ccomp }_{i t}\right)+\sum \beta_{j} \text { Governance characteristics }_{i t} \\
& +\sum \beta_{k} \text { CEO characteristics }_{i t} \quad+\sum \beta_{l} \text { Economic characteristics }_{i t} \\
& +\sum \beta_{m} \text { Industry Indicators }_{i t}+\sum \beta_{n} \text { Year Indicators }_{i t}+\varepsilon_{i t}
\end{aligned}
$$

The dependent variable (Comp) represents the level of CEO annual compensation and is examined alternately using three different measures: total annual compensation, equity compensation and annual bonus. Total annual compensation is measured using the natural 
logarithm of Execucomp's TDC1. This comprises: the CEO's salary, bonus, other annual compensation, the total value of restricted stock granted, the total value of stock options granted (using Black-Scholes), long-term incentive payouts and all other total (in thousands of dollars). Equity compensation is the natural logarithm of the dollar value of restricted stock granted and options granted. Bonus is the dollar value of bonuses earned during the fiscal year (in thousands of dollars). The experimental variables Femdir and F_ccomp, are indicator variables equal to one if there is one or more female directors on the board or compensation committee respectively. Alternative measures are also used in separate regressions which incorporate the percentage of female directors on a board or compensation committee (i.e. the extent to which the board or compensation committee is gender-diverse, Femdir\% and $F_{-}$ccomp $\left.\%\right)$. The coefficient on $F_{-}$ccomp $\left(F_{-}\right.$ccomp $\left.\%\right)$ is expected to be negative and significant. The coefficient on Femdir (Femdir\%) is expected to be insignificant however, since compensation decisions are a function of the compensation committee and not the board of directors. The remaining independent variables represent controls for governance, CEO and economic characteristics including industry and year indicators (outlined below).

\subsubsection{Corporate Governance Controls}

We include controls for governance characteristics predicted to be associated with CEO compensation. The first control is for board size (Bdsize) as larger boards are expected to be less effective monitors (Jensen 1993; Yermack 1996). The second control is the percentage of directors who are independent (Inddirs\%). Independent directors are deemed more effective monitors due to greater reputational costs (Fama and Jensen 1983; Coles et al. 2008). However, evidence exists consistent with board capture theory, suggesting that independent directors do not necessarily seek to maximize shareholder value (e.g. Core et al. 
1999). By including this control, we cater for the case that female directors may self-select to boards that are more independent or increase the number of independent directors appointed to boards on which they serve. Third, we include an indicator variable (Indcompcom) equal to one if the compensation committee is comprised wholly of independent directors, 0 otherwise.

\subsubsection{CEO characteristics}

The model also controls for CEO characteristics which reflect managerial power and experience. The first is CEO tenure, measured as the natural logarithm of the number of years of service of the current CEO ( $\left.\log \left(C E O \_t e n u r e\right)\right)$. The longer the CEO tenure, the greater the expected influence over the board. The second is an indicator variable equal to one if the CEO is also the chair of the board (CEO_chair), 0 otherwise. CEOs that are chair of their board are expected to receive higher compensation due to greater power over the board (Bebchuk et al. 2002, 2003; Grinstein and Hribar 2004) Further, CEOs that are also chairperson may receive higher compensation due to their holding two roles. The third, is an indicator variable equal to one if it is the CEO's first year of service at that firm (CEO_firstyear), 0 otherwise. CEOs new to a firm may receive higher compensation during that year due to sign on bonuses, or lower compensation due to performance incentives that are not realized until future years. The fourth control is an indicator variable equal to one if the CEO owns $5 \%$ or more of the company's stock (CEO5pct) and 0 otherwise. CEOs that have a higher portion of their wealth tied to the performance of the company are expected to act in a manner congruent with shareholders' interests and thus less likely to extract rents.

\subsubsection{Economic controls}


Controls are included for economic characteristics of the firm consistent with those documented in the compensation literature. Also included are industry and year indicators.

It has been documented that large and complex firms pay their executives more than smaller firms due to a greater demand for talent (Smith and Watts 1992). Therefore, firm size and complexity is controlled for using the natural logarithm of total sales revenue $(\log ($ Sale $))$. As a control for firms' investment opportunities, we employ the book-to-market ratio $(B M V)$. Companies with greater investment opportunities are associated with a higher demand for CEO talent and thus higher compensation (Murphy 1985). Because BMV is used, as opposed to the market-to-book ratio, the expected sign of the coefficient is negative (as a higher BMV indicates fewer investment opportunities). We also include firms' leverage (DE) measured as average total liabilities divided by average total assets. The level of executive pay is a function of firm performance (Core et al. 1999), therefore, controls are included for accounting and market measures of performance. The accounting measure is return on assets $(R O A)$ and the market measure is the company's annual stock return on common stock (RET). Firm risk is also expected to affect the level of CEO compensation but the direction is unclear. ${ }^{6}$ Consistent with prior studies, firm risk is controlled for using the standard deviation of common stock returns $(\log (\operatorname{Std} 3 R E T))$ and the standard deviation of return on assets measured over the prior three years $(\log (\operatorname{Std} 3 R O A)) .^{7}$

\subsection{Research Method to examine the Association between Excess CEO Compensation and Firm Performance}

To examine the association between excess CEO compensation and firm performance, we follow the methodology of Core et al. (1999; 2008). First, we estimate

\footnotetext{
${ }^{6}$ See for example, Core et al. (1999) and Smith and Watts (1992).

7 The natural logarithm of these measures is used due to a positively skewed distribution.
} 
expected total compensation using equation (2) which is based on the economic characteristics of the firm as demonstrated in the efficient contracting and compensation literature.

$$
\begin{aligned}
& \operatorname{Ln}(\text { Totalcomp })_{i t}=\beta_{0}+\beta_{1} \log (\mathrm{Sale})_{i t}+\beta_{2} \mathrm{BMV}_{i t}+\beta_{3} \mathrm{DE}_{\mathrm{it}}+\beta_{4} \mathrm{RET}_{\mathrm{it}} \\
& +\beta_{5} \mathrm{ROA}_{\mathrm{it}}+\beta_{6} \log (\mathrm{Std} 3 \mathrm{RET})_{i t}+\beta_{7} \log (\operatorname{Std} 3 \mathrm{ROA})_{i t}+\beta_{8} \log \left(\mathrm{CEO} \_t \text { tenure }\right)_{i t} \\
& +\sum \beta_{k} \text { Industry Indicators }_{i}+\varepsilon_{i t}
\end{aligned}
$$

Equation (2) is estimated using annual cross-sectional OLS regressions. Expected compensation is equal to the exponential value of Equation (2).

Excess compensation is computed by taking the difference between actual and expected compensation (Core et al 1999; 2008) ${ }^{8}$ :

$$
\% \text { Excess }_{i t}=\operatorname{Ln}\left(\text { Total Compensation }_{i t}\right)-\operatorname{Ln}\left(\text { Expected Compensation }_{i t}\right)
$$

We then examine the association between excess CEO compensation and subsequent firm-performance. ${ }^{9}$ Firm-performance is the return on assets for the subsequent one-year, two-years and average of the three-years after compensation is awarded. The following OLS regression is estimated separately for firms with an all-male compensation committee, gender-diverse compensation committee and then the pooled sample:

$$
\begin{aligned}
\operatorname{ROA}_{t+1 i}=\delta_{0}+ & \delta_{1} \% \text { Excess }_{t i}+\delta_{2} \log (\text { Sale })_{t i}+\delta_{3} B M V_{t i}+\delta_{4} \log (\operatorname{Std} 3 R O A)_{t i} \\
& +\delta_{i-n} \text { Industry Indicators } i+\delta_{i-n} \text { Year Indicators } t+\varepsilon_{i}
\end{aligned}
$$

\footnotetext{
${ }^{8}$ CEOs may receive excess compensation both as a reward for past performance and an incentive for future performance. We test the incentive aspect of CEO compensation as the reward component is incorporated by our method of estimating expected compensation shown in equation 2.

$9 \mathrm{We}$ also test the association between gender-diverse compensation committees and levels of excess compensation, discussed in section 4.4 Further Tests.
} 
ROA is replaced with subsequent one-year (ROA1), two-year (ROA2), and three year average ROA (avgROA3). Controls are included for factors which may predict subsequent ROA including sales $(\log ($ Sale $))$, book-to-market value (BMV), and risk $(\log (\operatorname{Std} 3 R O A))$ measured at t-1, as well as industry and year indicators. For tests on the total sample an interaction term is included for firms which have a gender-diverse compensation committees $\left(F_{-}\right.$ccomp $)$and $\%$ Excess.

\section{SAMPLE AND DATA}

The sample comprises of U.S. listed firms contained in The Corporate Library, Compustat Fundamentals Annual and Execucomp databases for the fiscal years 2002 to 2009. Observations are deleted if they report no data for the compensation committee as this indicates either missing data or that the firm-year does not have a compensation committee. This resulted in 113 deletions. Also deleted are observations missing CEO compensation data or data required for the control variables, and 105 observations for which total CEO compensation is less than $\$ 1 .^{10}$ The remaining sample results in 9,398 firm-years. ${ }^{11}$ Table 1 illustrates the sample. Panel A provides a breakdown of firms by year and Panel B displays the frequency of firms classified by industry with at least one female director on the compensation committee.

\section{(Insert Table 1 about here)}

The sample is not dominated by any particular year and no specific industry is driving the number of firms with gender-diverse compensation committees. The percentage of firms with a gender-diverse compensation committee varies within industry from $17.72 \%$ for the

\footnotetext{
10 These observations are either data errors or unusual circumstances. The next lowest value for total CEO compensation is $\$ 1,180$.

11 The sample is reduced to 7,552 observations for tests on equity compensation due to the removal of firms for which equity data is missing or equal to zero.
} 
Energy sector to $60.04 \%$ for Consumer Staples. Of the total sample, approximately $37 \%$ of firms have a gender-diverse compensation committee (Panel B).

\subsection{Descriptive Statistics}

Table 2 provides descriptive statistics for the total sample. ${ }^{12}$

\section{(Insert Table 2 about here)}

The average board size is 9.36 and on average $10 \%$ of directors are female. Across the sample the average compensation committee size is 3.58 and $11 \%$ of compensation committee members are female, however most firms have no female compensation committee members. Approximately $72 \%$ of directors are independent and most compensation committees are comprised wholly of independent directors. The average CEO tenure is just above eight years and $61 \%$ of CEOs are also the chair of their board. It is the CEO's first year of service for 5\% of the sample and only $9 \%$ of CEOs own five percent or more of the company's shares. Sales, total assets and market value are all positively skewed indicating that the majority of the sample are large companies. ${ }^{13}$

Table 3 displays the correlation matrix for all variables included in the analyses.

\section{(Insert Table 3 about here)}

The largest correlation that exists between variables used in the same regression is that of Sale with Total Compensation (0.41), and BMV with ROA (0.58). VIF and Tolerance analyses on regressions confirm that there are no multicollinearity concerns.

\footnotetext{
12 The descriptive statistics are shown prior to winsorizing the economic control variables at the 0.05 and 99.5 percentiles to remove the effect of significant outliers/data errors.

13 This is expected due to the Compustat database being biased towards large listed firms.
} 


\section{RESULTS}

\subsection{CEO Compensation and Gender-Diversity of Boards and Compensation}

\section{Committees}

Table 4 reports the results for the analysis of the association between gender-diverse boards and CEO compensation using Equation (1). The number of observations having a gender-diverse board but not compensation committee is $5,958 .{ }^{14}$ It is important to exclude firms that have a gender-diverse compensation committee in order to determine if it is gender-diversity of the board or gender-diversity of the compensation committee that matters in this context.

\section{(Insert Table 4 about here)}

Total compensation and equity are tested using OLS regressions and bonus is tested using a Tobit regression. ${ }^{15}$ Where heteroskedasticity is present, $t$-statistics are adjusted based on White's (1980) heteroskedasticity-adjusted standard errors. The adjusted R-squared of the OLS regressions is $40.91 \%$ for total compensation and $32.12 \%$ for equity, indicating reasonable explanatory power of the models.

The first three columns present regressions of total compensation, equity and bonus using an indicator variable (Femdir) to capture gender-diverse boards. The last three columns repeat these tests using a continuous measure for the fraction of the board that consists of female directors (Femdir\%). The variables measuring gender-diversity of the boards are not statistically significant for total compensation or equity, indicating that there is no association

\footnotetext{
${ }^{14}$ For tests on equity the sample reduces to 4,690 observations as we exclude firms for which equity data is missing or equal to zero.

15 Tobit regression is used for bonus due to the large number of zero bonuses in the sample. We also use rank regressions to test the robustness of results and then OLS regressions after having deleted zero bonus firms. The results do not change.
} 
between gender-diverse boards and these measures of CEO compensation. These results are consistent with those of Adams and Ferreira (2009) who also do not find statistically reliable evidence of an association between gender-diverse boards and CEO compensation. For bonus, the gender-diverse variables are negative and significant, however almost half the sample consists of firms that awarded no bonus to the CEO.

Table 5 repeats the same regressions now focusing on gender-diversity of the compensation committee.

\section{(Insert Table 5 about here)}

Again we use an indicator variable (columns 1-3) and a continuous variable (columns 4-6) to measure gender-diversity of the compensation committee. Across all columns we find that the different measures of gender-diversity of the compensation committee $\left(F \_\right.$ccomp and F_ccomp\%) are significant and negative. These results are not only statistically significant but are also economically significant, indicating a reduction in total compensation of $\$ 196,810$ (column 1) and a reduction in equity-based compensation of $\$ 163,641$ (column 2).

In columns 3 and 6 , we test if gender-diversity on the compensation committee is related to bonuses paid to CEOs. The results of these regressions confirm the findings on total CEO compensation as the coefficients are again negative and significant $(\mathrm{t}=-3.85$ and $\mathrm{t}=-4.03$ respectively).

The control variables in Table 5 which are significant in the models are in line with the findings of prior studies (see for example, Core et al. 1999, and Chalmers et al. 2006). Of the governance characteristics, the coefficient on the fraction of directors that are independent is positive and significant for total compensation and equity but not bonus. The independence of the compensation committee is positive and significant for bonuses but not total 
compensation or equity. These findings are not unlike those found by Wade et al. (1990) and Core et al. (1999).

Of the CEO characteristic controls, CEO tenure is not associated with total compensation or equity but is positive and significant for bonus. CEOs who are also the chair of their board receive significantly higher compensation on all measures, reflecting either the additional functions of the Chairman role or managerial power. First-time CEOs to the company receive higher equity pay and bonuses, reflective of incentives to perform well in future years. CEOs who own five percent or more of the company's stock receive less compensation on all three measures, consistent with the view of tying a CEO's wealth to the performance of the company to reduce agency conflicts.

Of the economic variables, large and complex firms pay their CEOs higher compensation, and firms with few investment opportunities pay their CEOs lower total compensation and equity, but higher bonuses. Total compensation and performance bonus appear to be associated with stock market returns as indicated by the positive and significant coefficient on RET. However, equity compensation is negatively associated with current market returns which reflect the fact that equity compensation is used to provide incentives for future performance and not given as a reward for current performance. Return on assets $(R O A)$ is also positive and significant for bonus but negative and significant for equity compensation. Greater risk as indicated by a larger standard deviation of performance measures is associated with higher total compensation and equity compensation. Leverage $(D E)$ does not appear to be associated with CEO compensation. These results are consistent with previous findings of Core et al. (1999) and Core et al. (2008).

\subsubsection{Propensity Score Matching}


A possible concern with the findings presented in Table 5 is self-selection bias. That is, the characteristics of firms with and without a gender-diverse compensation committee differ and it is these characteristics which are associated with lower levels of CEO compensation. To examine whether this is the case, Equation (1) is also tested on a subsample of firms matched within industry and year using a propensity score procedure. ${ }^{16}$ The matching is based on the probability of having at least one female director on the compensation committee (the treatment variable) depending upon firm size (Sale), board size (Bdsize) and the percentage of female directors on the board (Femdir\%). Firm size and board size are used due to evidence suggesting that female directors self-select to larger firms or that larger firms face greater pressure to include a female director on the board. ${ }^{17}$ It is necessary to control for the percentage of female directors on the board because the likelihood of having a female director on the compensation committee increases as women represent a greater proportion of the board. There are no prior theoretical arguments or empirical evidence to include any other economic or governance variables. Nevertheless, as an additional test we perform the propensity score procedure including all governance, CEO and economic variables in the logit regression. Results are unchanged using this subsample. Table 6 displays the descriptive statistics of the matched subsample. ${ }^{18}$

\section{(Insert Table 6 about here)}

The sample is reduced to 3,848 observations due to the unavailability of a matched firm for every firm-year observation. Bdsize and Femdir\% are similar across the samples

\footnotetext{
16 This involves estimating a yearly logit regression that models the probability of having a female on the compensation committee. See Rosenbaum (2001) for an overview of the procedure and applications, Rosenbaum and Rubin (1983) for a detailed theoretical discussion, and Armstrong et al. (2012) for a discussion and example of the procedure.

17 See Adams and Ferriera (2009), Carter et al. (2003) and Farrell and Hersch (2005).

18 In nearly all of the matching regressions used in the propensity score procedure sales is insignificant. The percentage of female directors on the board and board size are positive and significant.
} 
indicating that both the treatment and control groups have gender-diversity of the board but differ in the gender-diversity of the compensation committee. A Wilcoxon-Mann-Whitney test on the medians confirms that no statistically significant differences exist between these variables. Sale is larger for the gender-diverse subsample which works against documenting a negative relation between gender-diverse compensation committees and CEO compensation levels (given that compensation is also driven by size).

Table 7 displays the results of estimating Equation (1) for the matched subsample.

\section{(Insert Table 7 about here)}

Again the coefficient on $F_{-} c c o m p\left(F_{-} c c o m p \%\right)$ is negative and significant for total compensation $(\mathrm{p}<0.05)$ and equity $(\mathrm{P}<0.10)$. The economic significance to CEOs of having one or more female directors on the compensation committee is a reduction in total compensation of approximately $\$ 237,996$ and a reduction in equity of $\$ 203,698$ (columns 1

and 2, respectively). For bonus (columns 3 and 6) the coefficients on both gender-diversity measures are no-longer significant. The coefficients on control variables are similar to those reported in Table 4 using the total sample.

In summary, the results in Tables 5 and 7 indicate that CEO compensation is determined by the economic characteristics of the firm as well as by some other director characteristics and governance variables, including gender-diversity of the compensation committee.

\subsection{Excess CEO Compensation and Firm Performance}

To examine the association between excess compensation and subsequent firm performance we remove observations with missing data and are left with a sample of 6,264 
firm-years. We also remove from the sample those firms where the CEO retires in any one of the subsequent years over which the firm's performance is measured. CEOs that are retiring soon and newly hired CEOs have greater incentives to engage in earnings management. After the removal of these observations, the final sample for these tests is a total of 4,418 firmyears. The results of estimating equation 4 are reported in Table 8.

\section{(Insert Table 8 about here)}

Results are reported for firms with an all-male compensation committee, genderdiverse compensation committee, and then the pooled sample. The adjusted R-squares range from approximately $32 \%$ to $58 \%$ across the tests and the F-stats are significant (ranging from 42.85 to 221.58 ). Table 8 shows that excess compensation is negatively associated with subsequent return on assets for firms with an all-male compensation committee. The coefficient is negative and significant, ranging from -0.004 to -0.007 ( $\mathrm{p}<0.01)$. However, excess compensation is not related to subsequent ROA for firms with a gender-diverse compensation committee. The coefficient ranges from -0.001 to 0.002 but is not significant. For the pooled sample, \%Excess is negative and significant $(-0.004$ to $-0.007, \mathrm{p}<0.01)$ and the interaction term between gender-diverse compensation committees $\left(F_{-}\right.$ccomp $)$and \%Excess is positive and significant for ROAl and $\operatorname{avgROA3}(0.006, \mathrm{p}<0.05)$. This result suggests that gender-diversity of the compensation committee mitigates the negative relation between excess compensation and subsequent return on assets. All control variables are significant and in the predicted direction, indicating that firms with a larger $B M V$ and greater risk $(\log (\operatorname{Std} 3 R O A))$ generate lower return on assets, while larger firms indicated by $\log ($ Sales $)$ generate a higher return on assets. Together, these results provide some evidence that excess compensation results in a lower subsequent return on assets and that gender-diverse compensation committees appear to moderate the negative effects of excess compensation. 


\subsection{Further Tests}

We employ a number of additional tests to ascertain the robustness of the models. First, we model a Hausman test to test for the presence of endogeneity (Hausman, 1978). The Hausman test indicates that endogeneity is not an issue, which is consistent with the intuition that whilst women may self-select which companies they join as directors; there is no selfselection issue with respect to compensation committees (Kenser 1998; Bilimoria and Piderit 1994). Results remain unchanged after: clustering standard errors by firm, the deletion of firms belonging to the financial services industry, ${ }^{19}$ the use of rank regressions as an alternative to Tobit regressions for bonus, the use of OLS regressions after deleting observations with zero bonus, including additional governance variables (busy directors, grey directors, directors who are active CEOs of other companies, and if the firm has an institutional majority shareholder) and testing only independent female directors on the compensation committee. ${ }^{20}$

Additionally, tests are rerun after deleting firm-years in which a female serving on the compensation committee is a CEO of another company in the same year. Doing so removes female directors that may be less willing to pay higher compensation because they themselves receive lower compensation as CEOs in other firms; however, this did not change results. ${ }^{21}$ We also test the effect of directors who are serving on the compensation committee for the first time measured by the use of an indicator variable. First time servers may have the

\footnotetext{
19 The financial services industry (GICS 40) is regulated and known for high levels of executive compensation. Although industry indicators are included in the models, it is possible that the financial industry is influencing the results.

20 The inclusion of additional governance variables did not reduce the size or significance of the gender-diverse compensation committee variable. The majority of female directors in the sample are independent directors as opposed to executive directors and thus examining only independent female directors did not alter results.

21 There are many articles in the mainstream press that argue female business leaders receive lower compensation due to some form of gender discrimination; however, recent research shows this is not the case for CEOs (Bugeja et al., 2012).
} 
effect of lowering compensation as they are unaware of the pay setting process. Nevertheless, including this variable did not change results and it was not significant.

Finally, we also test the association between levels of excess CEO compensation and gender-diverse compensation committees. We regress excess compensation (\%Excess) on our gender-diverse measure while controlling for other governance factors (including board size, percentage of independent directors, independent compensation committees, CEO chair duality and CEO share holdings, and industry and year). We find that gender-diverse compensation committees are associated with lower levels of excess compensation (significant at the $1 \%$ level). These results indicate that gender-diverse compensation committees not only lower the levels of CEO compensation as shown in Table 7, but they also contract more efficiently resulting in CEO compensation contracts that are determined to a greater degree by the economic characteristics of the firm (hence resulting in a lower measure of excess compensation).

\section{DISCUSSION AND CONCLUSION}

Our findings make a number of important contributions. First, after controlling for the economic and governance characteristics of the firm, we find statistically reliable evidence that gender-diverse compensation committees are associated with lower levels of CEO compensation and excess compensation. These findings are consistent with the literature highlighting that gender-diversity of boards and board subcommittees can have economic effects, and underscore the economic benefit of the current public policy debate recommending board gender-diversity. Second, our results extend Core et al. (1999) by suggesting that gender-diversity of the compensation committee may be one factor that leads to 'stronger' governance, at least in terms of reducing the association between excess CEO compensation and firm performance. Third, our study suggests that just as policy makers 
make recommendations with respect to the independence of audit committees of the board, they could consider the need for gender-diversity of the compensation committee. This may be a less costly way of minimizing CEOs' excess pay than the Say on Pay legislation and/or prescribing target/limits for CEO pay.

We also need to recognise some of the limitations of our study. First, we do not document why women are intrinsically different from men, we simply document some associations between gender-diverse and non-gender-diverse compensation committees and CEO compensation. Second, our results are a joint test of our predictions and our modelling of excess compensation of CEOs. Future researchers may develop more refined models of excess compensation in the future. Finally, future research could address whether the sex of the CEO is associated with gender-diversity of boards.

\section{References}

Adams, R. and D. Ferreira. 2009. Women in the boardroom and their impact on governance and performance. Journal of Financial Economics 94: 291-309.

Adams, R. and Funk, P. 2012. Beyond the Glass Ceiling: Does Gender Matter? Management Science. 58:219-235.

Anderson, R. C. and Bizjak J. M. 2003. An Empirical examination of the role of the CEO and the compensation committee in structuring executive pay. Journal of Banking and Finance. 27:1323-1349.

Armstrong, C. S., Ittner, C. D. and Larcker, D. F. 2012. Corporate Governance, Compensation Consultants, and CEO pay levels. Review of Accounting Studies 17 (2): 322351. 
Bear, S., Rahman, N., Post, C., 2010. The Impact of Board Diversity and Gender Composition on Corporate Social Responsibility and Firm Reputation. Journal of Business Ethics 97, 207-221.

Bebchuk, L., J. Fried, and D. Walker. 2002. Managerial Power and Rent Extraction in the Design of Executive Compensation. The University of Chicago Law Review 69: 751-846. , and J. M. Fried. 2003. Executive Compensation as an Agency Problem. Journal of Economic Perspectives 17 (3): 71-92.

Bilimoria, D. and Piderit S. K. 1994, Board Committee Membership: Effect of Sex-based bias. Academy of Management Journal. 37:1453-1477.

Boulouta, I., 2013. Hidden Connections: The Link Between Board Gender Diversity and Corporate Social Performance. Journal of Business Ethics 113, 185-197.

Bugeja, M., Matolcsy, Z. P., and Spiropoulos, H. 2012. Is there a gender gap in CEO compensation? Journal of Corporate Finance 18 (4): 849-859.

Burns, N. and Minnick, K. 2013. Does Say-on-Pay Matter? Evidence from Say-on-Pay Proposals in the United States. The Financial Review 48: 233-258.

Campbell, K., Mínguez-Vera, A., 2008. Gender Diversity in the Boardroom and Firm Financial Performance. Journal of Business Ethics 83, 435-451.

Carter, D. A., B. J. Simkins, and G. Simpson. 2003. Corporate Governance, Board diversity and Firm Value. The Financial Review 38: 33-53.

Chalmers, K., P. Koh. and G. Stapledon. 2006. The determinants of CEO compensation: Rent extraction or labour demand?. The British Accounting Review 38: 259-275. 
Chapple, L. and Humphrey, J., 2014. Does Board Gender Diversity Have a Financial Impact? Evidence Using Stock Portfolio Performance. Journal of Business Ethics 122, 709-723.

Coles, J. L., N. D. Daniel, and L. Naveen. 2008. Boards: Does one size fit all?. Journal of Financial Economics 87 (2): 329-356.

Core, J. E., W. R. Guay, and D. F. Larcker. 2008. The power of the pen and executive compensation. Journal of Financial Economics 88: 1-25.

R. W. Holthausen, and D. F. Larcker. 1999. Corporate governance, chief executive officer compensation, and firm performance. Journal of Financial Economics 51 (3): 371406.

Correa, R. and Lel, U. 2013. Say on Pay Laws, Executive Compensation, CEO Pay Slice, and Firm Value around the World. Working Paper. Available in: SSRN eLibrary.

Cunat, V., Gine, M. and Gaudalupe, M. 2013. Say Pays! shareholder Voice and Firm Performance. Working Paper. Available in: SSRN eLibrary.

Cuomo, A. M. 2009. No Rhyme or Reason: The 'Heads I Win, Tails You Lose' Bank Bonus Culture. Attorney General State of New York. July 30.

Daily, C. M., Johnson, J. L., Ellstrand, A. E., and Dalton, D. R. 1998. Compensation Committee Compensation as a Determinant. Academy of Management Journal. 41:209-220.

Eagly, A. H. and Carli, L. L. 2003, 'The female leadership advantage: An evaluation of the evidence', Leadership Quarterly, Vol. 14, pp. 807-834.

Fama, E. F., and M. C. Jensen. 1983. Separation of ownership and control. Journal of Law \& Economics $26(2): 301-326$. 
Farrell, K. A., and P. L. Hersch. 2005. Additions to corporate boards: the effect of gender. Journal of Corporate Finance 11 (1/2):85-106.

Grinstein, Y., and P. Hribar. 2004. CEO compensation and incentives: Evidence from M\&A bonuses. Journal of Financial Economics 73 (1):119-143.

Gul, F. A., Srinidhi, B., and Ng, A. C. 2011. Does board gender diversity improve the informativeness of stock prices? Journal of Accounting and Economics 51 (3): 314-338.

Hausman, J. A. 1978. Specification Tests in Econometrics. Econometrica 46 (6): 1251-1271.

Huse, M. and Solberg, A. 2006. Gender-related boardroom dynamics: How Scandinavian women make and can make contributions on corporate boards. Women In Management Review 21 (2): 113-130.IES National Centre for Education Statistics. 2009. Table 301: Degrees in business conferred by degree-granting institutions, by level of degree and sex of student: Selected years, 1955-56 through 2007-08. Digest of Education Statistics.

Jensen, M. C. 1993. The Modern Industrial Revolution, Exit, and the Failure of Internal Control Systems. Journal of Applied Corporate Finance 22 (1): 43-58.

Joecks, J., Pull, K., Vetter, K., 2013. Gender Diversity in the Boardroom and Firm Performance: What Exactly Constitutes a 'Critical Mass?'. Journal of Business Ethics 118, $61-72$.

Kimbro, M. B. and Xu, D. 2013. Shareholders Have a Say on Executive Compensation: Evidence from Say-on-Pay in the United States. Working Paper. Available in: SSRN eLibrary.

Konrad, A. M., V. Kramer, and S. Erkut. 2008. Critical Mass: The Impact of Three or More Women on Corporate Boards. Organizational Dynamics 37 (2):145-164. 
Krishnan, G., Parsons, L., 2008. Getting to the Bottom Line: An Exploration of Gender and Earnings Quality. Journal of Business Ethics 78, 65-76.

Larker, D. F., Richardson, S. A. and Tuna, I. 2007. Corporate Governance, Accounting Outcomes and Organizational Performance. The Accounting Review 82 (4):963-1008.

Levi, M., Li, K. and Zhang, F. 2014. Director gender and mergers and acquisitions. Journal of Corporate Finance. Forthcoming.

Murphy, K. J. 1985. Corporate performance and managerial remuneration An Empirical Analysis. Journal of Accounting \& Economics 7 (1/2/3):11-42.

Murphy, M. 2010. Europe's bankers face bonus blues. Financial Times. October 7.

Parsons, C. and J. Puzzanghera. 2009. USA finance: Sharp words from Obama over Wall Street Bonuses. Los Angeles Times. January 30.

Rosenbaum, P. R. 2001. Observational Studies: Overview. In International Encyclopedia of the Social \& Behavioral Sciences, edited by J. S. Neil and B. B. Paul. Oxford: Pergamon, 10808-10815. , and D. B. Rubin. 1983. The Central Role of the Propensity Score in Observational Studies for Causal Effects. Biometrika 70 (1):41-55.

Schuman, I. 2010. Bill Would Limit Executive Compensation Paid by Systematically Significant Financial Institutions. Washington DC Employment Law Update. March 25.

Smith Jr, C. W., and R. L. Watts. 1992. The investment opportunity set and corporate financing, dividend, and compensation policies. Journal of Financial Economics 32 (3):263-292. 
Srinidhi, B., Gul, F. A. and Tsui, J. 2011. Female Directors and Earnings Quality. Contemporary Accounting Research. 28 (5):1610-1644.

Sun, J. Cahan, S. F., and Emanuel, D. 2009. Compensation committee governance quality, chief executive officer stock option grants, and future performance. Journal of Banking and Finance. 33 (8):1507-1519.

Traynor, I. 2012. Britain could scupper EU mandatory quotas for women on company boards. The Guardian, 17 September, Available at: http://www.guardian.co.uk/business/2012/sep/17/britain-eumandatory-quotas-women-boards

U.S. Department of Labor. 2009. Employment and Earnings, 2009 Annual Averages and the Monthly Labor Review. Bureau of Labor Statistics.

Wade, J., O'Reilly, C. A. and Chandratat, I.. 1990. Golden Parachutes: CEOs and the Exercise of Social Influence. Administrative Science Quarterly 35 (4):587-603.

Weisman, J. and J. S. Lublin. 2009. Obama Lays Out Limits on Executive Pay. The Wall Street Journal. February 5.

White, H. 1980. A heteroskedasticity consistent covaraiance matrix estimator and a direct test for heteroskedasticity. Econometrica 48 (4):817-838.

Yermack, D. 1996. Higher market valuation of companies with a small board of directors. Journal of Financial Economics 40 (2):185-211.

Zhang, J., Zhu, H., Ding, H.-b., 2013. Board Composition and Corporate Social Responsibility: An Empirical Investigation in the Post Sarbanes-Oxley Era. Journal of Business Ethics 114, 381-392. 


\section{Table 1}

Sample by Year and Industry

\begin{tabular}{cccc}
\hline Panel A: Frequency of firms with female directors on compensation committee by year \\
\hline Year & No. of Firms & $\begin{array}{c}\text { Firms with Femdirs on } \\
\text { Compensation Committee }\end{array}$ & $\begin{array}{c}\text { \% Firms with Femdirs on } \\
\text { Compensation Committee }\end{array}$ \\
\hline 2002 & 923 & 293 & 31.74 \\
2003 & 981 & 347 & 35.37 \\
2004 & 1,068 & 380 & 35.58 \\
2005 & 1,085 & 394 & 36.31 \\
2006 & 1,211 & 458 & 37.82 \\
2007 & 1,554 & 588 & 37.84 \\
2008 & 1,329 & 512 & 38.53 \\
2009 & 1,247 & 468 & 37.53 \\
Total & $\mathbf{9 , 3 9 8}$ & $\mathbf{3 , 4 4 0}$ & $\mathbf{3 6 . 6 0}$ \\
\hline
\end{tabular}

Panel B: Frequency of firms with female directors on compensation committee by industry

Firm-years with Femdirs

on Compensation

\begin{tabular}{cccc} 
Industry (2 digit GICS) & No. of Firm-years & Committee & \% Firm-years \\
\hline Energy & 508 & 90 & 17.72 \\
Materials & 598 & 230 & 38.46 \\
Industrials & 1,456 & 534 & 36.68 \\
Consumer Discretionary & 1,619 & 716 & 44.22 \\
Consumer Staples & 473 & 284 & 60.04 \\
Health Care & 998 & 349 & 34.97 \\
Financials & 1,314 & 480 & 36.53 \\
Information Technology & 1,856 & 476 & 25.65 \\
Telecommunications & 94 & 25 & 26.60 \\
Utilities & 482 & 256 & 53.11 \\
Total & $\mathbf{9 , 3 9 8}$ & $\mathbf{3 , 4 4 0}$ & $\mathbf{3 6 . 6 0}$ \\
\hline
\end{tabular}




\begin{tabular}{|c|c|c|c|c|c|}
\hline \multicolumn{6}{|c|}{ Table 2 Descriptive statistics for the total sample $(\mathbf{N}=9,398)$} \\
\hline Variable & Mean & Median & Std Dev & Q1 & Q3 \\
\hline Total comp $(\$ ’ 000)$ & $5,248.94$ & $3,139.98$ & $7,121.68$ & $1,528.45$ & $6,270.22$ \\
\hline Equity $(\$ \prime 000)$ & $2,901.76$ & $1,316.68$ & $5,339.99$ & 239.20 & $3,429.61$ \\
\hline Bonus $(\$ ’ 00)$ & 614.73 & 1.26 & $2,000.03$ & 0.00 & 636.30 \\
\hline Femdir\% & 0.10 & 0.09 & 0.08 & 0.00 & 0.14 \\
\hline F_ccomp $\%$ & 0.11 & 0.00 & 0.17 & 0.00 & 0.25 \\
\hline Bdsize & 9.36 & 9.00 & 2.54 & 8.00 & 11.00 \\
\hline CompCommitteeSize & 3.58 & 3.00 & 1.14 & 3.00 & 4.00 \\
\hline Inddirs $\%$ & 0.72 & 0.75 & 0.15 & 0.63 & 0.83 \\
\hline Indcompcom & 0.81 & 1.00 & 0.40 & 1.00 & 1.00 \\
\hline CEO_tenure & 8.16 & 6.00 & 7.91 & 3.00 & 11.00 \\
\hline CEO_chair & 0.61 & 1.00 & 0.49 & 0.00 & 1.00 \\
\hline CEO_firstyear & 0.05 & 0.00 & 0.21 & 0.00 & 0.00 \\
\hline CEO5pct & 0.09 & 0.00 & 0.28 & 0.00 & 0.00 \\
\hline Sale (\$million) & $6,077.84$ & $1,484.49$ & $17,694.19$ & 563.61 & $4,477.80$ \\
\hline$B M V$ & 0.69 & 0.68 & 0.27 & 0.48 & 0.88 \\
\hline$D E$ & 2.37 & 1.19 & 27.20 & 0.59 & 2.27 \\
\hline$R E T$ & 0.39 & 0.07 & 6.18 & -0.19 & 0.43 \\
\hline$R O A$ & 0.09 & 0.08 & 0.10 & 0.04 & 0.14 \\
\hline Std3RET & 1.38 & 0.35 & 23.50 & 0.19 & 0.68 \\
\hline Std3ROA & 0.03 & 0.02 & 0.04 & 0.01 & 0.04 \\
\hline AT (\$million) & $14,584.51$ & $2,014.72$ & $84,006.03$ & 698.35 & $6,657.08$ \\
\hline Mkval (\$million) & $7,875.01$ & $1,789.21$ & $24,443.83$ & 706.24 & $5,190.14$ \\
\hline \multicolumn{6}{|c|}{$\begin{array}{l}\text { Total comp is equal to Execucomp's TDC1, which comprises the CEO's: salary, bonus, other annual compensation, total value of restricted } \\
\text { stock granted, total value of stock options granted (using Black-Scholes), long-term incentive payouts and all other total (in thousands of } \\
\text { dollars). Equity is the dollar value of restricted stock granted and options granted. Bonus is the dollar value of bonus earned during the fiscal } \\
\text { year (in thousands of dollars). Femdir\% is the fraction of directors that are female. F_ccomp } \% \text { is the fraction of the compensation committee } \\
\text { that is made up of female directors. Bdsize represents the number of directors on the board. CompCommitteeSize is the size of the } \\
\text { compensation committee. Inddirs\% is the fraction of directors that are independent. Indcompcom is an indicator variable equal to } 1 \text { if the } \\
\text { compensation committee is comprised wholly of independent members, } 0 \text { otherwise. CEO_tenure is the number of years of service of the } \\
\text { current CEO. CEO_chair is an indicator variable equal to } 1 \text { if the CEO is also the chair of the board, } 0 \text { otherwise. CEO_firstyear is an } \\
\text { indicator variable equal to } 1 \text { if it is the CEO's first year at that firm, } 0 \text { otherwise. CEO5pct is an indicator variable equal to } 1 \text { if the CEO } \\
\text { owns five percent or more of the company's shares. Sale represents gross sales reduced by cash discounts, trade discounts, returned sales and } \\
\text { allowances for which credit is given to customers (measured in millions of dollars). BMV (book to market value) is measured as total } \\
\text { common equity divided by market value (measured in millions of dollars). DE equals average total liabilities divided by average total assets } \\
\text { (in millions of dollars). RET is the annual stock return. ROA is the annual return on assets (EBIT/avgAT). Std3RET and Std3ROA represent } \\
\text { the three year standard deviation of RET and ROA respectively. AT is the yearly average total assets (in millions of dollars). Mkval is equal } \\
\text { to the closing fiscal year share price multiplied by closing common shares outstanding (in millions of dollars). }\end{array}$} \\
\hline
\end{tabular}




\begin{tabular}{|c|c|c|c|c|c|c|c|c|c|c|c|c|c|c|c|c|c|c|c|}
\hline \multicolumn{20}{|c|}{ Table 3 Pearson Correlation Matrix } \\
\hline & (1) & (2) & (3) & (4) & (5) & (6) & $(7)$ & $(8)$ & $(9)$ & $(10)$ & $(11)$ & (12) & (13) & (14) & $(15)$ & $(16)$ & (17) & (18) & (19) \\
\hline (1) Total Comp & 1.00 & 0.89 & 0.49 & 0.12 & 0.06 & 0.22 & 0.08 & 0.02 & -0.02 & 0.11 & 0.01 & -0.06 & 0.41 & -0.07 & 0.06 & 0.03 & 0.11 & 0.01 & -0.05 \\
\hline (2) Equity & & 1.00 & 0.24 & 0.09 & 0.04 & 0.16 & 0.06 & 0.02 & -0.04 & 0.07 & 0.03 & -0.05 & 0.32 & -0.08 & 0.04 & 0.00 & 0.08 & 0.03 & -0.01 \\
\hline (3) Bonus & & & 1.00 & 0.02 & -0.01 & 0.10 & -0.04 & -0.01 & 0.05 & 0.08 & -0.01 & 0.00 & 0.18 & -0.01 & 0.04 & 0.07 & 0.08 & 0.02 & -0.04 \\
\hline (4) Femdir $\%$ & & & & 1.00 & 0.52 & 0.24 & 0.17 & 0.04 & -0.12 & 0.05 & 0.02 & -0.09 & 0.19 & 0.00 & 0.07 & -0.01 & 0.08 & -0.06 & -0.16 \\
\hline (5) $F \_$ccomp $\%$ & & & & & 1.00 & 0.12 & 0.10 & 0.04 & -0.09 & 0.00 & 0.01 & -0.07 & 0.12 & 0.02 & 0.05 & -0.02 & 0.04 & -0.03 & -0.10 \\
\hline (6) Bdsize & & & & & & 1.00 & 0.11 & -0.02 & -0.11 & -0.00 & 0.03 & -0.13 & 0.33 & 0.15 & 0.24 & -0.05 & -0.02 & -0.15 & -0.28 \\
\hline (7) Inddirs \% & & & & & & & 1.00 & 0.47 & -0.17 & 0.13 & -0.01 & -0.20 & 0.11 & 0.07 & 0.07 & -0.05 & -0.04 & -0.08 & -0.07 \\
\hline$(8)$ & & & & & & & & 1.00 & -0.01 & 0.03 & -0.01 & -0.03 & 0.03 & 0.03 & -0.00 & -0.01 & -0.00 & -0.04 & -0.00 \\
\hline \multicolumn{20}{|l|}{ Indcompcom } \\
\hline$(9)$ & & & & & & & & & 1.00 & 0.31 & -0.23 & 0.41 & -0.07 & -0.00 & -0.03 & -0.03 & 0.04 & 0.00 & -0.02 \\
\hline \multicolumn{20}{|l|}{ CEO_tenure } \\
\hline$(10)^{-}$ & & & & & & & & & & 1.00 & -0.17 & 0.14 & 0.09 & -0.01 & 0.02 & 0.04 & 0.05 & 0.01 & -0.06 \\
\hline \multicolumn{20}{|l|}{ CEO_chair } \\
\hline$(11)$ & & & & & & & & & & & 1.00 & -0.06 & 0.00 & -0.01 & 0.00 & -0.02 & -0.02 & -0.00 & 0.02 \\
\hline \multicolumn{20}{|l|}{ CEO_firstyear } \\
\hline (12) CEO5pct & & & & & & & & & & & & 1.00 & -0.07 & -0.04 & -0.03 & 0.01 & 0.03 & 0.03 & 0.04 \\
\hline (13) Sale & & & & & & & & & & & & & 1.00 & 0.02 & 0.10 & -0.02 & 0.05 & -0.06 & -0.13 \\
\hline (14) $B M V$ & & & & & & & & & & & & & & 1.00 & 0.22 & -0.26 & -0.58 & -0.15 & -0.16 \\
\hline (15) $D E$ & & & & & & & & & & & & & & & 1.00 & -0.03 & -0.13 & -0.07 & -0.15 \\
\hline (16) RET & & & & & & & & & & & & & & & & 1.00 & 0.15 & 0.25 & 0.03 \\
\hline (17) $R O A$ & & & & & & & & & & & & & & & & & 1.00 & 0.10 & -0.11 \\
\hline (18) Std3RET & & & & & & & & & & & & & & & & & & 1.00 & 0.19 \\
\hline (19) Std3ROA & & & & & & & & & & & & & & & & & & & 1.00 \\
\hline $\begin{array}{l}\text { Total comp is equal } \\
\text { long-term incentive } \\
\text { thousands of dollars } \\
\text { board. Inddirs\% is t } \\
\text { is the number of yea } \\
\text { CEO's first year at t } \\
\text { discounts, returned s s } \\
\text { millions of dollars). } \\
\text { represent the three y }\end{array}$ & $\begin{array}{l}\text { fraction } \\
\text { of servi } \\
\text { t firm, } 0 \\
\text { es and a } \\
E \text { equal } \\
\text { ir standa }\end{array}$ & $\begin{array}{l}\text { directo } \\
\text { of the c } \\
\text { herwise } \\
\text { wances } \\
\text { verage t } \\
\text { deviatio }\end{array}$ & $\begin{array}{l}\text { that are } \\
\text { rent CEC } \\
\text { CEO5pct } \\
\text { r which } \\
\text { l liabilit } \\
\text { of } R E T\end{array}$ & $\begin{array}{l}C E O \_c h \\
\text { an indic } \\
\text { dit is gi } \\
\text { divided } \\
\text { ROA re }\end{array}$ & $\begin{array}{l}\text { Indcomp } \\
\text { is an in } \\
\text { or variabl } \\
\text { to cust } \\
\text { y average } \\
\text { ectively. }\end{array}$ & $\begin{array}{l}\text { om is at } \\
\text { icator vi } \\
\text { equal t } \\
\text { mers (m } \\
\text { total ass }\end{array}$ & $\begin{array}{l}\text { able equ } \\
\text { if the C } \\
\text { sured in } \\
\text { (in mill }\end{array}$ & $\begin{array}{l}\text { iable eq } \\
\text { o } 1 \text { if th } \\
\text { owns f } \\
\text { lions of } \\
\text { s of dol }\end{array}$ & $\begin{array}{l}\text { al to } 1 \text { if } \\
\text { CEO is } \\
\text { e percen }\end{array}$ & $\begin{array}{l}\text { e comp } \\
\text { o the ch } \\
\text { r more } \\
\text { IV (boo } \\
\text { the anı }\end{array}$ & $\begin{array}{l}\text { ation c } \\
\text { of the } \\
\text { he con } \\
\text { mark } \\
\text { stock }\end{array}$ & $\begin{array}{l}\text { nittee is } \\
\text { rd, } 0 \text { oth } \\
\text { ay's shar } \\
\text { alue) is } 1 \\
\text { irn. } R O A\end{array}$ & $\begin{array}{l}\text { Sale } \mathrm{r} \\
\text { wise. C } \\
\text { asured } \\
\text { the an }\end{array}$ & $\begin{array}{l}\text { firsty } \\
\text { esents } \\
\text { total co } \\
\text { ll returr }\end{array}$ & $\begin{array}{l}\text { Bdsize } \\
\text { depend } \\
\text { is an in } \\
\text { ss sales } \\
\text { on equ } \\
\text { assets }\end{array}$ & $\begin{array}{l}\text { t membe } \\
\text { ator var } \\
\text { luced by } \\
\text { divided } \\
\text { BIT/avg }\end{array}$ & $\begin{array}{l}\text { s, } 0 \text { othe } \\
\text { ble equa } \\
\text { ash disc } \\
\text { y marke } \\
\text { T). Std3 }\end{array}$ & $\begin{array}{l}\text { iscal year } \\
\text { of directo } \\
\text { ise. } C E O \\
\text { o } 1 \text { if it is } \\
\text { nts, trade } \\
\text { alue (me } \\
T \text { and } S t c\end{array}$ & $\begin{array}{l}\text { s), } \\
\text { in } \\
\text { s on the } \\
\text { tenure } \\
\text { he } \\
\text { ured in } \\
\text { ROA }\end{array}$ \\
\hline
\end{tabular}




\begin{tabular}{|c|c|c|c|c|c|c|}
\hline \multicolumn{7}{|c|}{$\begin{array}{l}\text { Pooled cross-sectional regressions of CEO compensation on Board gender-diversity } \\
\text { Comp }=\text { Femdir }+B d s i z e+\operatorname{Inddirs} \%+\operatorname{Ind} \text { dcompcom }+\log \left(C E O \_ \text {tenure }\right)+C E O \_ \text {chair }+ \text { CEO_firstyear }+ \text { CEO5pct }+ \\
\log (\text { Sale })+B M V+D E+R E T+R O A+\log (\operatorname{Std} 3 R E T)+\log (\text { Std } 3 R O A)+\text { Industry Indicators }+ \text { Year Indicators }\end{array}$} \\
\hline Parameter & $\begin{array}{c}\text { Total } \\
\text { Comp }\end{array}$ & Equity & Bonus & Total Comp & Equity & Bonus \\
\hline & (1) & (2) & (3) & (4) & (5) & (6) \\
\hline Intercept & $\begin{array}{l}4.16 * * * \\
(33.23)\end{array}$ & $\begin{array}{l}3.38 * * * \\
(17.64)\end{array}$ & $\begin{array}{l}-4700.24 * * * \\
(-8.73)\end{array}$ & $\begin{array}{l}4.16 * * * \\
(33.27)\end{array}$ & $\begin{array}{l}3.39 * * * \\
(17.71)\end{array}$ & $\begin{array}{l}-4605.21 * * * \\
(-8.58)\end{array}$ \\
\hline Femdir & $\begin{array}{l}\text { 0.04 } \\
(1.39)\end{array}$ & $\begin{array}{l}-0.01 \\
(-0.13)\end{array}$ & $\begin{array}{l}-429.52 * * * \\
(-3.71)\end{array}$ & & & \\
\hline Femdir\% & & & & $\begin{array}{l}\mathbf{0 . 1 8} \\
(1.16)\end{array}$ & $\begin{array}{l}0.09 \\
(0.37)\end{array}$ & $\begin{array}{l}-2789.38 * * * \\
(-3.89)\end{array}$ \\
\hline Bdsize & $\begin{array}{l}0.00 \\
(0.89)\end{array}$ & $\begin{array}{l}-0.01 \\
(-1.37)\end{array}$ & $\begin{array}{l}37.40 \\
(1.55)\end{array}$ & $\begin{array}{l}0.01 \\
(1.15)\end{array}$ & $\begin{array}{l}-0.01 \\
(-1.48)\end{array}$ & $\begin{array}{l}24.48 \\
(1.06)\end{array}$ \\
\hline Inddirs $\%$ & $\begin{array}{l}0.50 * * * \\
(5.65)\end{array}$ & $\begin{array}{l}0.46^{* * * *} \\
(3.08)\end{array}$ & $\begin{array}{l}-669.16^{*} \\
(-1.75)\end{array}$ & $\begin{array}{l}0.51 * * * \\
(5.67)\end{array}$ & $\begin{array}{l}0.45)^{* * * *} \\
(3.03\end{array}$ & $\begin{array}{l}-685.43 * \\
(-1.79)\end{array}$ \\
\hline Indcompcom & $\begin{array}{l}-0.01 \\
(-0.42)\end{array}$ & $\begin{array}{l}-0.05 \\
(-0.99)\end{array}$ & $\begin{array}{l}209.43 \\
(1.58)\end{array}$ & $\begin{array}{l}-0.01 \\
(-0.44)\end{array}$ & $\begin{array}{l}-0.05 \\
(-0.98)\end{array}$ & $\begin{array}{l}218.79 * \\
(1.65)\end{array}$ \\
\hline Log(CEO_tenure $)$ & $\begin{array}{l}-0.01 \\
(-0.37)\end{array}$ & $\begin{array}{l}-0.02 \\
(-0.88)\end{array}$ & $\begin{array}{l}326.92 * * * \\
(4.47)\end{array}$ & $\begin{array}{l}-0.01 \\
(-0.37)\end{array}$ & $\begin{array}{l}-0.02 \\
(-0.84)\end{array}$ & $\begin{array}{l}321.80 * * * \\
(4.40)\end{array}$ \\
\hline CEO_chair & $\begin{array}{l}0.16 * * * \\
(6.29)\end{array}$ & $\begin{array}{l}0.21 * * * \\
(5.26)\end{array}$ & $\begin{array}{l}183.07 \\
(1.63)\end{array}$ & $\begin{array}{l}0.16 * * * \\
(6.29)\end{array}$ & $\begin{array}{l}0.21 * * * \\
(5.25)\end{array}$ & $\begin{array}{l}186.75^{*} \\
(1.66)\end{array}$ \\
\hline CEO_firstyear & $\begin{array}{l}0.01 \\
(0.09)\end{array}$ & $\begin{array}{l}0.16^{*} \\
(1.71)\end{array}$ & $\begin{array}{l}775.16^{* * * *} \\
(2.95)\end{array}$ & $\begin{array}{l}0.01 \\
(0.09)\end{array}$ & $\begin{array}{l}0.17 * \\
(1.72)\end{array}$ & $\begin{array}{l}771.09 * * * \\
(2.94)\end{array}$ \\
\hline CEO5pct & $\begin{array}{l}-0.37 * * * \\
(-7.52)\end{array}$ & $\begin{array}{l}-0.11 \\
(-1.52)\end{array}$ & $\begin{array}{l}-320.84 * \\
(-1.87)\end{array}$ & $\begin{array}{l}-0.37 * * * \\
(-7.53)\end{array}$ & $\begin{array}{l}-0.11 \\
(-1.51)\end{array}$ & $\begin{array}{l}-321.38 * \\
(-1.87)\end{array}$ \\
\hline $\log ($ Sale $)$ & $\begin{array}{l}0.43 * * * \\
(40.34)\end{array}$ & $\begin{array}{l}0.54 * * * \\
(36.08)\end{array}$ & $\begin{array}{l}412.12 * * * \\
(10.06)\end{array}$ & $\begin{array}{l}0.43 * * * \\
(40.55)\end{array}$ & $\begin{array}{l}0.53 * * * \\
(36.27)\end{array}$ & $\begin{array}{l}413.08 * * * \\
(10.09)\end{array}$ \\
\hline$B M V$ & $\begin{array}{l}-0.33 * * * \\
(-5.65)\end{array}$ & $\begin{array}{l}-0.92 * * * \\
(-9.81)\end{array}$ & $\begin{array}{l}490.87 * \\
(1.94)\end{array}$ & $\begin{array}{l}-0.33 * * * \\
(-5.65)\end{array}$ & $\begin{array}{l}-0.92 \\
(-9.80)\end{array}$ & $\begin{array}{l}466.95^{*} \\
(1.85)\end{array}$ \\
\hline$D E$ & $\begin{array}{l}-0.01 * * * \\
(-2.68)\end{array}$ & $\begin{array}{l}-0.01 * * * \\
(-3.06)\end{array}$ & $\begin{array}{l}-37.18 * * * \\
(-2.68)\end{array}$ & $\begin{array}{l}-0.01 * * * \\
(-2.68)\end{array}$ & $\begin{array}{l}-0.01 * * * \\
(-3.08)\end{array}$ & $\begin{array}{l}-36.79 * * * \\
(-2.66)\end{array}$ \\
\hline RET & $\begin{array}{l}0.04 * * * \\
(2.72)\end{array}$ & $\begin{array}{l}-0.08 * * * \\
(-3.43)\end{array}$ & $\begin{array}{l}136.30 * * \\
(2.38)\end{array}$ & $\begin{array}{l}0.04 * * * \\
(2.73)\end{array}$ & $\begin{array}{l}-0.08 * * * \\
(-3.41)\end{array}$ & $\begin{array}{l}131.09 * * \\
(2.28)\end{array}$ \\
\hline$R O A$ & $\begin{array}{l}0.00 \\
(0.03)\end{array}$ & $\begin{array}{l}-0.62 * * * \\
(-2.59)\end{array}$ & $\begin{array}{l}3217.80 * * * \\
(4.99)\end{array}$ & $\begin{array}{l}0.00 \\
(0.02)\end{array}$ & $\begin{array}{l}-0.62 * * * \\
(-2.58)\end{array}$ & $\begin{array}{l}3189.58 * * * \\
(4.95)\end{array}$ \\
\hline $\log (\operatorname{Std} 3 R E T)$ & $\begin{array}{l}0.01 \\
(0.14)\end{array}$ & $\begin{array}{l}0.12 * \\
(1.95)\end{array}$ & $\begin{array}{l}52.02 \\
(0.37)\end{array}$ & $\begin{array}{l}0.00 \\
(0.12)\end{array}$ & $\begin{array}{l}0.12 * * \\
(1.97)\end{array}$ & $\begin{array}{l}54.73 \\
(0.39)\end{array}$ \\
\hline $\log (\operatorname{Std} 3 R O A)$ & $\begin{array}{l}0.61^{*} \\
(1.67)\end{array}$ & $\begin{array}{l}2.22 * * * \\
(4.40)\end{array}$ & $\begin{array}{l}101.77 \\
(0.92)\end{array}$ & $\begin{array}{l}0.60^{*} \\
(1.65)\end{array}$ & $\begin{array}{l}2.24 * * * \\
(4.43)\end{array}$ & $\begin{array}{l}101.42 \\
(0.91)\end{array}$ \\
\hline Industry Indicators & Yes & Yes & Yes & Yes & Yes & Yes \\
\hline Year Indicators & Yes & Yes & Yes & Yes & Yes & Yes \\
\hline $\operatorname{Adj} R-S q$ & 0.4091 & 0.3212 & & 0.4091 & 0.3212 & \\
\hline$F$ value & $134.05^{* * *}$ & $72.56 * * *$ & & $134.02 * * *$ & $72.57 * * *$ & \\
\hline Sigma & & & $3138.04 * * *$ & & & $3137.77 * * *$ \\
\hline No. of zero bonus & & & 2867 & & & 2867 \\
\hline$N$ & 5,958 & 4,690 & 5,958 & 5,958 & 4,690 & 5,958 \\
\hline $\begin{array}{l}\text { * is significant at } 10 \% \\
\text { percentiles. Total com } \\
\text { used for Total comp a } \\
\text { which comprises the } \\
\text { granted (using Black-s } \\
\text { the dollar value of rest } \\
\text { of dollars). Femdir is } \\
\text { fraction of the board t } \\
\text { directors that are inde } \\
\text { independent members, } \\
\text { indicator variable equa } \\
\text { the CEO's first year at } \\
\text { company's shares. Log } \\
\text { allowances for which c } \\
\text { (measured in millions } \\
\text { annual stock return. } R \\
\text { three year standard dev }\end{array}$ & $\begin{array}{l}\text { s significant } \\
\text { d equity } t \text {-stati } \\
\text { obit regressio } \\
\text { s: salary, bont } \\
\text { les), long-terr } \\
\text { d stock grante } \\
\text { dicator variab } \\
\text { onsists of fem } \\
\text { lent. Indcomp } \\
\text { herwise. } L o g( \\
1 \text { if the CEO } \\
t \text { firm, } 0 \text { othe } \\
\text { ) is the natur } \\
\text { is given to cu } \\
\text { ollars). } D E \text { e } \\
\text { s the annual r }\end{array}$ & $\begin{array}{l}\% \text {, and } * * * \text { is } \\
\text { s are based on } \\
\text { are used on th } \\
\text { other annual cc } \\
\text { ccentive payou } \\
\text { d options grant } \\
\text { equal to } 1 \text { if th } \\
\text { directors. Bds } \\
\text { is an indicat } \\
\left.O \_t e n u r e\right) \text { is lo } \\
\text { lso the chair of } \\
\text { se. CEO5pct is } \\
\text { garithm of gro } \\
\text { mers. BMV (bo } \\
\text { ls average tota } \\
\text { rn on assets (E } \\
\text { A respectively }\end{array}$ & $\begin{array}{l}\text { icant at } 1 \% \text {. Ecc } \\
\text { te's (1980) heter } \\
\text { lar value of Bor } \\
\text { nsation, total va } \\
\text { d all other total } \\
\text { 3onus is the dolla } \\
\text { s one or more } \mathrm{f} \\
\text { presents the nu } \\
\text { riable equal to } \\
\text { s } 1 \text { of the numb } \\
\text { ooard, } 0 \text { otherwi } \\
\text { ndicator variabl } \\
\text { les (in \$mil) red } \\
\text { market value) i } \\
\text { ilities divided b } \\
\text { avgAT). Log(Stc }\end{array}$ & $\begin{array}{l}\text { mic variables have } \\
\text { edasticity-adjustec } \\
\text { Total Comp is th } \\
\text { of restricted stocl } \\
\text { thousands of dolla } \\
\text { alue of bonus earn } \\
\text { ale directors on th } \\
\text { er of directors on } \\
\text { f the compensatio } \\
\text { f years of service } \\
C E O \text { firstyear is } \\
\text { qual to } 1 \text { if the C } \\
\text { d by cash discoun } \\
\text { easured as total co } \\
\text { verage total asset } \\
E T) \text { and } \log (S t d 3\end{array}$ & $\begin{array}{l}\text { een winsorize } \\
\text { standard errors } \\
\text { natural log of } \\
\text { granted, total } \\
\text { ). Equity is th } \\
\text { d during the fis } \\
\text { board, } 0 \text { other } \\
\text { e board. Inddi } \\
\text { committee is } \\
\text { f the current } \mathrm{C} \\
\text { indicator var } \\
\mathrm{O} \text { owns five } \mathrm{p} \\
\text {, trade discour } \\
\text { mon equity di } \\
\text { (in millions o } \\
O A \text { ) represent }\end{array}$ & $\begin{array}{l}\text { he } 0.05 \text { and } 99.5 \\
S \text { regressions are } \\
\text { cucomp's TDC1, } \\
\text { of stock options } \\
\text { ural logarithm of } \\
\text { ear (in thousands } \\
\text { Femdir\% is the } \\
\text { is the fraction of } \\
\text { prised wholly of } \\
C E O \text { chair is an } \\
\text { equal to } 1 \text { if it is } \\
\text { it or more of the } \\
\text { eturned sales and } \\
\text { by market value } \\
\text { lars). RET is the } \\
\text { aatural log of the }\end{array}$ \\
\hline
\end{tabular}




\begin{tabular}{|c|c|c|c|c|c|c|}
\hline \multicolumn{7}{|c|}{$\begin{array}{l}\text { Pooled cross-sectional regressions of CEO compensation on compensation committee gender-diversity } \\
\text { Comp }=F \_c c o m p+B d s i z e+I n d d i r s \%+I n d c o m p c o m+L o g\left(C E O \_t e n u r e\right)+C E O \_ \text {chair }+C E O \_ \text {firstyear }+C E O 5 p c t+ \\
L o g(\text { Sale })+B M V+D E+R E T+R O A+L o g(\operatorname{Std} 3 R E T)+L o g(\text { Std } 3 R O A)+\text { Industry Indicators }+ \text { Year Indicators }\end{array}$} \\
\hline Parameter & $\begin{array}{c}\text { Total } \\
\text { Comp }\end{array}$ & Equity & Bonus & Total Comp & Equity & Bonus \\
\hline & $(1)$ & $(2)$ & (3) & $(4)$ & $(5)$ & $(6)$ \\
\hline Intercept & $\begin{array}{l}4.23 \\
(43.93)\end{array}$ & $\begin{array}{l}3.44 * * * \\
(23.45)\end{array}$ & $\begin{array}{l}-3918.73 * * * \\
(-10.16)\end{array}$ & $\begin{array}{l}4.24 * * * \\
(44.06)\end{array}$ & $\begin{array}{l}3.45 * * * \\
(23.16)\end{array}$ & $\begin{array}{l}-3873.06^{* * * *} \\
(-10.06)\end{array}$ \\
\hline$F_{-}$ccomp & $\begin{array}{l}-0.05 * * * \\
(-2.91)\end{array}$ & $\begin{array}{l}-0.07 * * * \\
(-2.69)\end{array}$ & $\begin{array}{l}-290.39 * * * \\
(-3.85)\end{array}$ & & & \\
\hline$F_{-}$ccomp\% & & & & $\begin{array}{l}-0.14 * * * \\
(-2.74)\end{array}$ & $\begin{array}{l}-0.21 * * \\
(-2.57)\end{array}$ & $\begin{array}{l}-876.04 * * * \\
(-4.03)\end{array}$ \\
\hline Bdsize & $\begin{array}{l}0.01 * * * \\
(3.06)\end{array}$ & $\begin{array}{l}-0.01 \\
(-1.01)\end{array}$ & $\begin{array}{l}-2.07 \\
(-0.12)\end{array}$ & $\begin{array}{l}0.01 * * * \\
(2.96)\end{array}$ & $\begin{array}{l}-0.01 \\
(-1.09)\end{array}$ & $\begin{array}{l}-4.28 \\
(-0.26)\end{array}$ \\
\hline Inddirs $\%$ & $\begin{array}{l}0.54 * * * \\
(7.60)\end{array}$ & $\begin{array}{l}0.50 * * * \\
(4.13)\end{array}$ & $\begin{array}{l}-1078.04 * * * \\
(-3.79)\end{array}$ & $\begin{array}{l}0.53 * * * \\
(7.45)\end{array}$ & $\begin{array}{l}0.48 * * * \\
(4.02)\end{array}$ & $\begin{array}{l}-1137.39 * * * \\
(-4.02)\end{array}$ \\
\hline Indcompcom & $\begin{array}{l}-0.02 \\
(-0.98)\end{array}$ & $\begin{array}{l}-0.05 \\
(-1.45)\end{array}$ & $\begin{array}{l}235.43 * * \\
(2.43)\end{array}$ & $\begin{array}{l}-0.02 \\
(-0.88)\end{array}$ & $\begin{array}{l}-0.05 \\
(-1.36)\end{array}$ & $\begin{array}{l}249.23 * * \\
(2.57)\end{array}$ \\
\hline Log(CEO_tenure $)$ & $\begin{array}{l}-0.01 \\
(-0.57)\end{array}$ & $\begin{array}{l}-0.01 \\
(-0.66)\end{array}$ & $\begin{array}{l}197.51 * * * \\
(3.71)\end{array}$ & $\begin{array}{l}-0.01 \\
(-0.55)\end{array}$ & $\begin{array}{l}-0.01 \\
(-0.64)\end{array}$ & $\begin{array}{l}198.14 * * * \\
(3.72)\end{array}$ \\
\hline CEO_chair & $\begin{array}{l}0.18 * * * \\
(8.93)\end{array}$ & $\begin{array}{l}0.20 * * * \\
(6.71)\end{array}$ & $\begin{array}{l}248.76^{* * * *} \\
(3.08)\end{array}$ & $\begin{array}{l}0.18^{* * *} \\
(8.91)\end{array}$ & $\begin{array}{l}0.20 * * * \\
(6.69)\end{array}$ & $\begin{array}{l}246.71 * * * \\
(3.06)\end{array}$ \\
\hline CEO_firstyear & $\begin{array}{l}-0.03 \\
(-0.52)\end{array}$ & $\begin{array}{l}0.13 * \\
(1.82)\end{array}$ & $\begin{array}{l}555.27 * * * \\
(3.04)\end{array}$ & $\begin{array}{l}-0.03 \\
(-0.54)\end{array}$ & $\begin{array}{l}0.13^{*} \\
(1.80)\end{array}$ & $\begin{array}{l}548.47 * * * \\
(3.01)\end{array}$ \\
\hline CEO5pct & $\begin{array}{l}-0.37 * * * \\
(-8.86)\end{array}$ & $\begin{array}{l}-0.16 * * * \\
(-2.60)\end{array}$ & $\begin{array}{l}-273.27 * * \\
(-2.03)\end{array}$ & $\begin{array}{l}-0.37 * * * \\
(-8.87)\end{array}$ & $\begin{array}{l}-0.16 * * * \\
(-2.61)\end{array}$ & $\begin{array}{l}-275.02 * * \\
(-2.04)\end{array}$ \\
\hline $\log ($ Sale $)$ & $\begin{array}{l}0.42 * * * \\
(53.54)\end{array}$ & $\begin{array}{l}0.52 * * * \\
(48.90)\end{array}$ & $\begin{array}{l}374.06 * * * \\
(13.36)\end{array}$ & $\begin{array}{l}0.42 * * * \\
(53.78)\end{array}$ & $\begin{array}{l}0.52 * * * \\
(48.83)\end{array}$ & $\begin{array}{l}372.81 * * * \\
(13.34)\end{array}$ \\
\hline$B M V$ & $\begin{array}{l}-0.43 * * * \\
(-8.94)\end{array}$ & $\begin{array}{l}-1.02 * * * \\
(-13.93)\end{array}$ & $\begin{array}{l}627.32 * * * \\
(3.27)\end{array}$ & $\begin{array}{l}-0.43 * * * \\
(-8.95)\end{array}$ & $\begin{array}{l}-1.03 * * * \\
(-13.94)\end{array}$ & $\begin{array}{l}626.56 * * * \\
(3.27)\end{array}$ \\
\hline$D E$ & $\begin{array}{l}-0.00 \\
(-0.64)\end{array}$ & $\begin{array}{l}-0.01 \\
(-1.57)\end{array}$ & $\begin{array}{l}-7.70 \\
(-0.94)\end{array}$ & $\begin{array}{l}-0.00 \\
(-0.62)\end{array}$ & $\begin{array}{l}-0.01 \\
(-1.57)\end{array}$ & $\begin{array}{l}-7.43 \\
(-0.91)\end{array}$ \\
\hline$R E T$ & $\begin{array}{l}0.03 * * * \\
(2.63)\end{array}$ & $\begin{array}{l}-0.08 * * * \\
(-4.49)\end{array}$ & $\begin{array}{l}188.09 * * * \\
(4.51)\end{array}$ & $\begin{array}{l}0.03 * * * \\
(2.62)\end{array}$ & $\begin{array}{l}-0.08 * * * \\
(-4.51)\end{array}$ & $\begin{array}{l}186.91 * * * \\
(4.48)\end{array}$ \\
\hline$R O A$ & $\begin{array}{l}0.15 \\
(1.04)\end{array}$ & $\begin{array}{l}-0.51 * * \\
(-2.54)\end{array}$ & $\begin{array}{l}3550.40 * * * \\
(6.95)\end{array}$ & $\begin{array}{l}0.15 \\
(1.03)\end{array}$ & $\begin{array}{l}-0.51 * * \\
(-2.56)\end{array}$ & $\begin{array}{l}3543.14 * * * \\
(6.94)\end{array}$ \\
\hline $\log (\operatorname{Std} 3 R E T)$ & $\begin{array}{l}0.05 \\
(1.56)\end{array}$ & $\begin{array}{l}0.13 * * * \\
(2.79)\end{array}$ & $\begin{array}{l}6.19 \\
(0.06)\end{array}$ & $\begin{array}{l}0.05 \\
(1.55)\end{array}$ & $\begin{array}{l}0.13 * * * \\
(2.79)\end{array}$ & $\begin{array}{l}5.81 \\
(0.05)\end{array}$ \\
\hline $\log (\operatorname{Std} 3 R O A)$ & $\begin{array}{l}0.69 * * \\
(2.27)\end{array}$ & $\begin{array}{l}2.38 * * * \\
(5.53)\end{array}$ & $\begin{array}{l}645.76 * * * \\
(8.66)\end{array}$ & $\begin{array}{l}0.70 * * \\
(2.29)\end{array}$ & $\begin{array}{l}2.39 * * * \\
(5.56)\end{array}$ & $\begin{array}{l}664.49 * * * \\
(8.90)\end{array}$ \\
\hline Industry Indicators & Yes & Yes & Yes & Yes & Yes & Yes \\
\hline Year Indicators & Yes & Yes & Yes & Yes & Yes & Yes \\
\hline $\operatorname{Adj} R-S q$ & 0.4422 & 0.3552 & & 0.4423 & 0.3552 & \\
\hline F value & $241.36^{* * *}$ & $135.20 * * *$ & & $241.36 * * *$ & $135.18 * * *$ & \\
\hline Sigma & & & $2823.73 * * *$ & & & $2823.46^{* * *}$ \\
\hline No. of zero bonus & & & 4671 & & & 4671 \\
\hline$N$ & 9,398 & 7,552 & 9,398 & 9,398 & 7,552 & 9,398 \\
\hline $\begin{array}{l}* \text { is significant at } 10 \% \\
\text { percentiles. Total com } \\
\text { used for Total comp a } \\
\text { which comprises the } \\
\text { granted (using Black-s } \\
\text { the dollar value of rest } \\
\text { of dollars). F_ccomp is } \\
F_{\text {_ }} \text { ccomp\% is the frac } \\
\text { independent. Bdsize re } \\
\text { is an indicator varial } \\
\text { Log(CEO_tenure) is lo } \\
\text { CEO is also the chair } \\
\text { otherwise. CEOSpct is } \\
\text { natural logarithm of gr } \\
\text { to customers. BMV (bo } \\
D E \text { equals average tota } \\
\text { return on assets (EBIT } \\
\text { ROA respectively. }\end{array}$ & $\begin{array}{l}\text { is significant } \\
\text { equity } t \text {-stati } \\
\text { obit regressio } \\
\text { s: salary, bont } \\
\text { les), long-terr } \\
\text { d stock grantec } \\
\text { ndicator varia } \\
\text { of the comper } \\
\text { nts the numbe } \\
\text { equal to } 1 \text { if } \\
\text { us } 1 \text { of the nu } \\
\text { e board, } 0 \text { oth } \\
\text { indicator vari } \\
\text { ales (in } \$ \text { mil) } \\
\text { o market valu } \\
\text { bilities dividec } \\
\text { AT). } \log (\operatorname{Std} 3 \\
\end{array}$ & $\begin{array}{l}\% \text {, and } * * * \text { is } \\
\text { s are based on } \\
\text { are used on th } \\
\text { other annual cc } \\
\text { ncentive payou } \\
\text { d options grant } \\
\text { equal to } 1 \text { if th } \\
\text { tion committee } \\
\text { f directors on t } \\
\text { ne compensati } \\
\text { er of years of } \\
\text { ise. CEO_first } \\
\text { equal to } 1 \text { if } \\
\text { uced by cash d } \\
\text { s measured as } \\
\text { y average total } \\
T) \text { and } L o g(S t d \\
\end{array}$ & $\begin{array}{l}\text { icant at } 1 \% \text {. Ecc } \\
\text { te's (1980) heter } \\
\text { lar value of Bor } \\
\text { nsation, total va } \\
\mathrm{d} \text { all other total } \\
\text { 3onus is the dolle } \\
5 \text { one or more fer } \\
\text { consists of fem } \\
\text { ard. Inddirs\% is } \\
\text { ommittee is co } \\
\text { ce of the current } \\
\text { is an indicator v } \\
\text { CEO owns five } \\
\text { ints, trade disco } \\
\text { common equity } \\
\text { s (in millions of } \\
\text { A) represent the }\end{array}$ & $\begin{array}{l}\text { mic variables have } \\
\text { edasticity-adjuste } \\
\text { Total Comp is th } \\
\text { of restricted stocl } \\
\text { thousands of dolli } \\
\text { alue of bonus earn } \\
\text { e directors on the } \\
\text { directors. Inddirs } \\
\text { e fraction of direct } \\
\text { rised wholly of } \\
\text { OO. CEO_chair is } \\
\text { ble equal to } 1 \text { if i } \\
\text { cent or more of tl } \\
\text {, returned sales an } \\
\text { ided by market v } \\
\text { llars). RET is the } \\
\text { ural log of the thr }\end{array}$ & $\begin{array}{l}\text { been winsorize } \\
\text { standard errors } \\
\text { natural log o } \\
\text { granted, total } \\
\text { s). Equity is th } \\
\text { d during the fis } \\
\text { ompensation cc } \\
6 \text { is the fractio } \\
\text { rs that are inde } \\
\text { adependent m } \\
\text { n indicator val } \\
\text { is the CEO's fi } \\
\text { company's sh } \\
\text { allowances fo } \\
\text { ue (measured } \\
\text { nual stock retı } \\
\text { year standard }\end{array}$ & $\begin{array}{l}\text { the } 0.05 \text { and } 99.5 \\
S \text { regressions are } \\
\text { cucomp's TDC1, } \\
\text { of stock options } \\
\text { tural logarithm of } \\
\text { ear (in thousands } \\
\text { ittee, } 0 \text { otherwise. } \\
\text { directors that are } \\
\text { lent. Indcompcom } \\
\text { rs, } 0 \text { otherwise. } \\
\text { equal to } 1 \text { if the } \\
\text { ear at that firm, } 0 \\
\text { Log(Sale) is the } \\
\text { ch credit is given } \\
\text { llions of dollars). } \\
\text { ROA is the annual } \\
\text { ation of RET and }\end{array}$ \\
\hline
\end{tabular}




\begin{tabular}{|c|c|c|c|c|c|c|}
\hline \multicolumn{7}{|c|}{$\begin{array}{l}\text { Table } 6 \\
\begin{array}{c}\text { Descriptive statistics of matched firms with an all-male compensation committee and firms with a gender- } \\
\text { diverse compensation committee }(\mathrm{N}=3,848)\end{array}\end{array}$} \\
\hline & \multicolumn{2}{|c|}{$\begin{array}{l}\text { All-male compensation } \\
\text { committee firms } \\
(\mathrm{N}=1,924)\end{array}$} & \multicolumn{2}{|c|}{$\begin{array}{l}\text { Gender-diverse } \\
\text { compensation committee } \\
\text { firms }(\mathrm{N}=1,924)\end{array}$} & \multicolumn{2}{|c|}{$\begin{array}{l}\text { Wilcoxon-Mann-Whitney } \\
\text { test on medians }\end{array}$} \\
\hline Parameter & Mean & Median & Mean & Median & $\mathrm{Z}$ & $\operatorname{Pr}>|Z|$ \\
\hline Total comp (\$'000) & $5,472.88$ & $3,496.47$ & $5,166.57$ & $3,409.75$ & 0.52 & 0.61 \\
\hline Equity $(\$ 000)$ & $3,052.92$ & $1,521.99$ & $2,800.70$ & $1,430.56$ & 1.29 & 0.20 \\
\hline Bonus (\$'000) & 576.09 & 0.00 & 479.74 & 0.00 & -0.13 & 0.90 \\
\hline Femdir\% & 0.12 & 0.11 & 0.12 & 0.11 & -0.66 & 0.51 \\
\hline$F_{-}$ccomp $\%$ & 0.00 & 0.00 & 0.30 & 0.25 & $-62.02 * * *$ & 0.00 \\
\hline$\overline{B d}$ size & 9.85 & 10.00 & 9.81 & 10.00 & 0.79 & 0.43 \\
\hline Inddirs\% & 0.73 & 0.75 & 0.75 & 0.78 & $-2.95 * * *$ & 0.00 \\
\hline Indcompcom & 0.81 & 1.00 & 0.82 & 1.00 & -0.41 & 0.68 \\
\hline CEO_tenure & 7.95 & 5.00 & 7.12 & 5.00 & 1.63 & 0.10 \\
\hline CEO_chair & 0.60 & 1.00 & 0.59 & 1.00 & 0.82 & 0.41 \\
\hline CEO_firstyear & 0.05 & 0.00 & 0.06 & 0.00 & -1.21 & 0.22 \\
\hline CEO5pct & 0.08 & 0.00 & 0.06 & 0.00 & $3.08 * * *$ & 0.00 \\
\hline Sale (\$million) & $5,835.82$ & $1,767.22$ & $6,066.29$ & $2,067.44$ & $-2.64 * * *$ & 0.01 \\
\hline$B M V$ & 0.69 & 0.70 & 0.70 & 0.71 & -0.77 & 0.44 \\
\hline$D E$ & 2.72 & 1.29 & 1.42 & 1.36 & -1.42 & 0.16 \\
\hline RET & 0.28 & 0.04 & 0.23 & 0.05 & -0.19 & 0.85 \\
\hline$R O A$ & 0.09 & 0.08 & 0.09 & 0.08 & 0.45 & 0.65 \\
\hline Std3RET & 0.88 & 0.31 & 1.18 & 0.33 & $-1.74 *$ & 0.08 \\
\hline Std3ROA & 0.03 & 0.02 & 0.02 & 0.01 & $2.06 * *$ & 0.04 \\
\hline AT (\$million) & $17,599.74$ & $2,434.76$ & $15,468.28$ & $2,752.78$ & -1.55 & 0.12 \\
\hline Mkval (\$million) & $8,217.53$ & $2,049.93$ & $7,467.04$ & $2,139.05$ & -0.64 & 0.52 \\
\hline \multicolumn{7}{|c|}{$\begin{array}{l}\text { Total comp is equal to Execucomp's TDC1, which comprises the CEO's: salary, bonus, other annual compensation, total value of restricted } \\
\text { stock granted, total value of stock options granted (using Black-Scholes), long-term incentive payouts, and all other total (in thousands of } \\
\text { dollars). Equity is the dollar value of restricted stock granted and options granted. Bonus is the dollar value of bonus earned during the fiscal } \\
\text { year (in thousands of dollars). Femdir\% is the fraction of directors that are female. F_ccomp\% is the fraction of the compensation committee } \\
\text { that is made up of female directors. Bdsize represents the number of directors on the board. Inddirs\% is the fraction of directors that are } \\
\text { independent. Indcompcom is an indicator variable equal to } 1 \text { if the compensation committee is comprised wholly of independent members, } 0 \\
\text { otherwise. CEO_tenure is the number of years of service of the current CEO. CEO_chair is an indicator variable equal to } 1 \text { if the CEO is } \\
\text { also the chair of the board, } 0 \text { otherwise. CEO_firstyear is an indicator variable equal to } 1 \text { if it is the CEO's first year at that firm, } 0 \text { otherwise. } \\
C E O 5 p c t \text { is an indicator variable equal to } 1 \text { if the CEO owns five percent or more of the company's shares. Sale represents gross sales } \\
\text { reduced by cash discounts, trade discounts, returned sales and allowances for which credit is given to customers (measured in millions of } \\
\text { dollars). BMV (book to market value) is measured as total common equity divided by market value (measured in millions of dollars). DE } \\
\text { equals average total liabilities divided by average total assets (in millions of dollars). RET is the annual stock return. ROA is the annual } \\
\text { return on assets (EBIT/avgAT). Std3RET and Std3ROA represent the three year standard deviation of } R E T \text { and } R O A \text { respectively. AT is the } \\
\text { yearly average total assets (in millions of dollars). Mkval is equal to the closing fiscal year share price multiplied by closing common shares } \\
\text { outstanding (in millions of dollars). }\end{array}$} \\
\hline
\end{tabular}




\begin{tabular}{|c|c|c|c|c|c|c|}
\hline \multicolumn{7}{|c|}{$\begin{array}{l}\text { Pooled cross-sectional regressions of CEO compensation using the matched subsample }(\mathbf{N}=\mathbf{3 , 8 4 8}) \\
\text { Comp }=F \_ \text {ccomp }+B d s i z e+I n d d i r s \%+I n d \operatorname{simpcom}+\log \left(C E O \_ \text {tenure }\right)+C E O \_ \text {chair }+C E O \_ \text {firstyear }+C E O 5 p c t+ \\
\log (\text { Sale })+B M V+D E+R E T+R O A+\log (\operatorname{Std} 3 R E T)+L o g(\text { Std } 3 R O A)+\text { Industry Indicators }+ \text { Year Indicators }\end{array}$} \\
\hline Parameter & $\begin{array}{r}\text { Total } \\
\text { Comp }\end{array}$ & Equity & Bonus & Total Comp & Equity & Bonus \\
\hline & $(1)$ & $(2)$ & (3) & $(4)$ & $(5)$ & $(6)$ \\
\hline Intercept & $\begin{array}{l}4.46 * * * \\
(28.80)\end{array}$ & $\begin{array}{l}3.88 * * * \\
(17.04)\end{array}$ & $\begin{array}{l}-2096.58 * * * \\
(-4.36)\end{array}$ & $\begin{array}{l}4.47 * * * \\
(28.83)\end{array}$ & $\begin{array}{l}3.89 * * * \\
(17.07)\end{array}$ & $\begin{array}{l}-2098.08 * * * \\
(-4.36)\end{array}$ \\
\hline F_ccomp & $\begin{array}{l}-0.06 * * \\
(-2.31)\end{array}$ & $\begin{array}{l}-0.07 * \\
(-1.71)\end{array}$ & $\begin{array}{l}-116.00 \\
(-1.48)\end{array}$ & & & \\
\hline F_ccomp\% & & & & $\begin{array}{l}-0.19 * * \\
(-2.29)\end{array}$ & $\begin{array}{l}-0.22 * \\
(-1.71)\end{array}$ & $\begin{array}{l}-233.26 \\
(-0.98)\end{array}$ \\
\hline Bdsize & $\begin{array}{l}0.03 * * * \\
(4.41)\end{array}$ & $\begin{array}{l}-0.02^{*} \\
(-1.75)\end{array}$ & $\begin{array}{l}15.77 \\
(0.78)\end{array}$ & $\begin{array}{l}0.03 * * * \\
(4.31)\end{array}$ & $\begin{array}{l}-0.02 * \\
(-1.82)\end{array}$ & $\begin{array}{l}15.37 \\
(0.76)\end{array}$ \\
\hline Inddirs\% & $\begin{array}{l}0.54 * * * \\
(4.69)\end{array}$ & $\begin{array}{l}0.69 * * * \\
(3.29)\end{array}$ & $\begin{array}{l}-917.03 * * * \\
(-2.66)\end{array}$ & $\begin{array}{l}0.53 * * * \\
(4.59)\end{array}$ & $\begin{array}{l}0.67 * * * \\
(3.23)\end{array}$ & $\begin{array}{l}-935.65 * * * \\
(-2.71)\end{array}$ \\
\hline Indcompcom & $\begin{array}{l}-0.03 \\
(-0.95)\end{array}$ & $\begin{array}{l}-0.08 \\
(-1.31)\end{array}$ & $\begin{array}{l}128.10 \\
(1.14)\end{array}$ & $\begin{array}{l}-0.03 \\
(-0.83)\end{array}$ & $\begin{array}{l}-0.08 \\
(-1.25)\end{array}$ & $\begin{array}{l}134.02 \\
(1.19)\end{array}$ \\
\hline Log(CEO_tenure $)$ & $\begin{array}{l}-0.02 \\
(-0.86)\end{array}$ & $\begin{array}{l}-0.00 \\
(-0.11)\end{array}$ & $\begin{array}{l}29.30 \\
(0.47)\end{array}$ & $\begin{array}{l}-0.02 \\
(-0.89)\end{array}$ & $\begin{array}{l}-0.00 \\
(-0.13)\end{array}$ & $\begin{array}{l}29.36 \\
(0.47)\end{array}$ \\
\hline CEO_chair & $\begin{array}{l}0.20 * * * \\
(6.51)\end{array}$ & $\begin{array}{l}0.16 * * * \\
(3.35)\end{array}$ & $\begin{array}{l}156.90 * \\
(1.70)\end{array}$ & $\begin{array}{l}0.20 * * * \\
(6.51)\end{array}$ & $\begin{array}{l}0.16 * * * \\
(3.35)\end{array}$ & $\begin{array}{l}157.72 * \\
(1.71)\end{array}$ \\
\hline CEO_firstyear & $\begin{array}{l}-0.09 \\
(-1.15)\end{array}$ & $\begin{array}{l}0.12 \\
(1.15)\end{array}$ & $\begin{array}{l}170.27 \\
(0.87)\end{array}$ & $\begin{array}{l}-0.09 \\
(-1.18)\end{array}$ & $\begin{array}{l}0.12 \\
(1.15)\end{array}$ & $\begin{array}{l}167.08 \\
(0.85)\end{array}$ \\
\hline CEO5pct & $\begin{array}{l}-0.37 * * * \\
(-4.90)\end{array}$ & $\begin{array}{l}-0.33 * * \\
(-2.51)\end{array}$ & $\begin{array}{l}-163.79 \\
(-0.96)\end{array}$ & $\begin{array}{l}-0.37 * * * \\
(-4.90)\end{array}$ & $\begin{array}{l}-0.33 * * \\
(-2.51)\end{array}$ & $\begin{array}{l}-159.22 \\
(-0.93)\end{array}$ \\
\hline $\log ($ Sale $)$ & $\begin{array}{l}0.39 * * * \\
(33.38)\end{array}$ & $\begin{array}{l}0.52 * * * \\
(29.94)\end{array}$ & $\begin{array}{l}328.53^{* * * *} \\
(10.23)\end{array}$ & $\begin{array}{l}0.39 * * * \\
(33.48)\end{array}$ & $\begin{array}{l}0.52 * * * \\
(29.91)\end{array}$ & $\begin{array}{l}327.97 * * * \\
(10.21)\end{array}$ \\
\hline$B M V$ & $\begin{array}{l}-0.53 * * * \\
(-7.09)\end{array}$ & $\begin{array}{l}-1.08 * * * \\
(-9.62)\end{array}$ & $\begin{array}{l}55.12 \\
(0.24)\end{array}$ & $\begin{array}{l}-0.53 * * * \\
(-7.11)\end{array}$ & $\begin{array}{l}-1.09 * * * \\
(-9.65)\end{array}$ & $\begin{array}{l}50.38 \\
(0.22)\end{array}$ \\
\hline$D E$ & $\begin{array}{l}0.00 \\
(0.40)\end{array}$ & $\begin{array}{l}0.00 \\
(0.74)\end{array}$ & $\begin{array}{l}7.40 * * \\
(2.42)\end{array}$ & $\begin{array}{l}0.00 \\
(0.42)\end{array}$ & $\begin{array}{l}0.00 \\
(0.76)\end{array}$ & $\begin{array}{l}7.45 * * \\
(2.43)\end{array}$ \\
\hline RET & $\begin{array}{l}0.01 * * * \\
(3.33)\end{array}$ & $\begin{array}{l}0.01 \\
(1.42)\end{array}$ & $\begin{array}{l}35.76^{*} \\
(1.74)\end{array}$ & $\begin{array}{l}0.01 * * * \\
(3.32)\end{array}$ & $\begin{array}{l}0.01 \\
(1.40)\end{array}$ & $\begin{array}{l}35.90 * \\
(1.75)\end{array}$ \\
\hline$R O A$ & $\begin{array}{l}0.14 \\
(0.59)\end{array}$ & $\begin{array}{l}-0.65 * * \\
(-2.11)\end{array}$ & $\begin{array}{l}1806.86 * * * \\
(2.91)\end{array}$ & $\begin{array}{l}0.13 \\
(0.56)\end{array}$ & $\begin{array}{l}-0.65 * * \\
(-2.12)\end{array}$ & $\begin{array}{l}1798.26^{* * * *} \\
(2.90)\end{array}$ \\
\hline $\log (\operatorname{Std} 3 R E T)$ & $\begin{array}{l}0.01 \\
(0.95)\end{array}$ & $\begin{array}{l}0.01 \\
(0.73)\end{array}$ & $\begin{array}{l}-13.19 \\
(-0.33)\end{array}$ & $\begin{array}{l}0.01 \\
(0.93)\end{array}$ & $\begin{array}{l}0.01 \\
(0.72)\end{array}$ & $\begin{array}{l}-14.63 \\
(-0.36)\end{array}$ \\
\hline $\log (\operatorname{Std} 3 R O A)$ & $\begin{array}{l}0.02 \\
(1.63)\end{array}$ & $\begin{array}{l}0.06 * * * \\
(2.64)\end{array}$ & $\begin{array}{l}86.79 * * \\
(2.22)\end{array}$ & $\begin{array}{l}0.02 \\
(1.62)\end{array}$ & $\begin{array}{l}0.06 * * * \\
(2.64)\end{array}$ & $\begin{array}{l}87.67 * * \\
(2.24)\end{array}$ \\
\hline Industry Indicators & Yes & Yes & Yes & Yes & Yes & Yes \\
\hline Year Indicators & Yes & Yes & Yes & Yes & Yes & Yes \\
\hline $\operatorname{Adj} R-S q$ & 0.4225 & 0.3304 & & $91.88 * * *$ & 0.3305 & \\
\hline F value & $91.80 * * *$ & $49.86 * * *$ & & 0.4228 & $49.88 * * *$ & \\
\hline $\begin{array}{l}\text { Sigma } \\
\text { No. of zero bonus }\end{array}$ & & & $\begin{array}{l}2008.66^{* * * *} \\
2,112\end{array}$ & & & $\begin{array}{l}2009.43 * * * \\
2,112\end{array}$ \\
\hline $\begin{array}{l}\text { For tests on equity com } \\
\text { significant at } 1 \% \text {. Econ } \\
\text { (1980) heteroskedasticit } \\
\text { value of Bonus. Total } \\
\text { compensation, total val } \\
\text { payouts and all other to } \\
\text { granted. Bonus is the do } \\
1 \text { if there is one or mo } \\
\text { committee that consists } \\
\text { directors on the board. } \\
\text { compensation committe } \\
\text { of service of the curre } \\
\text { CEO firstyear is an ind } \\
\text { to } 1 \text { if the CEO owns fi } \\
\text { cash discounts, trade d } \\
\text { measured as total comn } \\
\text { average total assets (in I } \\
\text { and } \log (\operatorname{Std} 3 R O A) \text { repr }\end{array}$ & $\begin{array}{l}\text { sation } \mathrm{N} \text { is } \mathrm{r} \\
\text { c variables } \mathrm{h} \\
\text { djusted stand } \\
\text { mp is the } \\
\text { of restricted } \\
\text { in thousands } \\
\text { value of bon } \\
\text { emale direct } \\
\text { female direc } \\
\text { dirs\% is the } \\
\text { comprised } \mathrm{w} \\
\text { EO. CEO_c } \\
\text { or variable ec } \\
\text { percent or } \mathrm{m} \\
\text { unts, returne } \\
\text { equity divide } \\
\text { ons of dollar } \\
\text { t the natural }\end{array}$ & $\begin{array}{l}\text { ced to } 3,070 \mathrm{~m} \\
\text { been winsoriz } \\
\text { errors. OLS re } \\
\text { ral log of Ex } \\
\text { ck granted, tot } \\
\text { lollars). Equity } \\
\text { earned during tl } \\
\text { on the compen } \\
\text { Inddirs\% is } \\
\text { ction of directc } \\
\text { ly of independe } \\
\text { is an indicate } \\
\text { to } 1 \text { if it is the } \\
\text { of the company } \\
\text { les and allow: } \\
\text { y market value } \\
\text { RET is the annu } \\
\text { of the three yea }\end{array}$ & $\begin{array}{l}\text { ed observations. } \\
\text { the } 0.05 \text { and } 99 \\
\text { sions are used fo } \\
\text { omp's TDC1, w } \\
\text { alue of stock opt } \\
\text { e natural logarith } \\
\text { scal year (in thou } \\
\text { n committee, } 0 \\
\text { raction of direct } \\
\text { at are independe } \\
\text { lembers, } 0 \text { othery } \\
\text { riable equal to } 1 \\
\text { 's first year at th } \\
\text { ares. Log(Sale) } \\
\text { s for which cred } \\
\text { asured in million } \\
\text { ock return. ROA i } \\
\text { ndard deviation o }\end{array}$ & $\begin{array}{l}\text { is significant at } 10 \\
\text { percentiles. Total } \\
\text { Cotal comp and To } \\
\text { ch comprises the } \\
\text { ns granted (using } \\
\text { of the dollar value } \\
\text { nds of dollars). } F_{-} \\
\text {erwise. } F_{-} \text {ccomp } \\
\text { that are indepen } \\
\text { Indcompcom is } \\
\text { e. Log (CEO_tenur } \\
\mathrm{f} \text { the CEO is also } \\
\text { firm, } 0 \text { otherwise. } \\
\text { the natural logarith } \\
\text { is given to custon } \\
\text { of dollars). DE eqL } \\
\text { the annual return o } \\
\text { RET and ROA resp }\end{array}$ & $\begin{array}{l}\text {, ** is signific } \\
\text { omp } t \text {-statistics } \\
\text { it regressions } \\
\text { CEO's: salary, } \\
\text { Black-sScholes) } \\
\text { f restricted stoc } \\
\text { omp is an indi } \\
\text { is the fraction } \\
\text { nt. Bdsize rep } \\
\text { indicator vari } \\
\text { is log plus } 1 \text { c } \\
\text { the chair of th } \\
E O 5 p c t \text { is an in } \\
\text { n of gross sales } \\
\text { ers. BMV (boo } \\
\text { ls average tota } \\
\text { assets (EBIT/a } \\
\text { ctively. }\end{array}$ & $\begin{array}{l}\text { t } 5 \%, \text { and } * * * \text { is } \\
\text { based on White's } \\
\text { ised on the dollar } \\
\text { us, other annual } \\
\text { g-term incentive } \\
\text { anted and options } \\
\text { variable equal to } \\
\text { the compensation } \\
\text { ts the number of } \\
\text { equal to } 1 \text { if the } \\
\text { number of years } \\
\text { ard, } 0 \text { otherwise. } \\
\text { tor variable equal } \\
\$ \text { mil) reduced by } \\
\text { market value) is } \\
\text { ilities divided by } \\
\text { T). Log(Std3RET) }\end{array}$ \\
\hline
\end{tabular}




\section{Table 8}

Pooled cross-sectional regressions of excess compensation on subsequent ROA

$R O A=$ ExcessComp $+\log ($ Sale $+B M V+\log ($ Std $3 R O A)+$ Industry Indicators + Year Indicators

\begin{tabular}{|c|c|c|c|c|c|c|c|c|c|}
\hline & \multicolumn{3}{|c|}{ All-male $(\mathrm{N}=\mathbf{2 , 8 4 0})$} & \multicolumn{3}{|c|}{ Gender-diverse $(\mathbf{N}=\mathbf{1 , 5 7 8})$} & \multicolumn{3}{|c|}{ Pooled $(\mathrm{N}=4,418)$} \\
\hline & ROA1 & ROA2 & avgROA3 & ROA1 & ROA2 & $\operatorname{avgROA3}$ & ROA1 & ROA2 & avgROA3 \\
\hline Intercept & $0.191 * * *$ & $0.192 * * *$ & $0.184 * * *$ & $0.203 * * *$ & $0.179 * * *$ & $0.186^{* * *}$ & $0.197 * * *$ & $0.188 * * *$ & $0.186^{* * *}$ \\
\hline & $(17.04)$ & $(14.89)$ & $(16.26)$ & $(19.19)$ & $(12.69)$ & $(15.46)$ & $(25.19)$ & $(20.11)$ & $(22.71)$ \\
\hline \%Excess & $\begin{array}{l}-0.004 * * * * \\
(-2.60)\end{array}$ & $\begin{array}{l}-0.007 * * * * \\
(-3.99)\end{array}$ & $\begin{array}{l}-0.007 * * * \\
(-4.65)\end{array}$ & $\begin{array}{l}0.002 \\
(0.97)\end{array}$ & $\begin{array}{l}-0.002 \\
(-0.75)\end{array}$ & $\begin{array}{l}-0.001 \\
(-0.49)\end{array}$ & $\begin{array}{l}-0.004 * * * * \\
(-2.63)\end{array}$ & $\begin{array}{l}-0.007 * * * \\
(-4.08)\end{array}$ & $\begin{array}{l}-0.007 * * * \\
(-4.74)\end{array}$ \\
\hline $\log ($ Sale $)$ & $\begin{array}{l}0.007 * * * \\
(7.19)\end{array}$ & $\begin{array}{l}0.005^{* * * *} \\
(4.47)\end{array}$ & $\begin{array}{l}0.005^{* * *} \\
(5.68)\end{array}$ & $\begin{array}{l}0.006^{* * * *} \\
(6.82)\end{array}$ & $\begin{array}{l}0.007 * * * \\
(5.14)\end{array}$ & $\begin{array}{l}0.006^{* * * *} \\
(6.07)\end{array}$ & $\begin{array}{l}0.006^{* * * *} \\
(9.76)\end{array}$ & $\begin{array}{l}0.006 * * * \\
(7.05)\end{array}$ & $\begin{array}{l}0.006 * * * \\
(8.39)\end{array}$ \\
\hline BMV & $\begin{array}{l}-0.208 * * * \\
(-34.64)\end{array}$ & $\begin{array}{l}-0.173 * * * \\
(-23.65)\end{array}$ & $\begin{array}{l}-0.173^{* * *} \\
(-27.46)\end{array}$ & $\begin{array}{l}-0.216 \\
(-32.47)\end{array}$ & $\begin{array}{l}-0.175^{* * *} \\
(-19.23)\end{array}$ & $\begin{array}{l}-0.182 * * * \\
(-24.72)\end{array}$ & $\begin{array}{l}-0.212 * * * \\
(-46.44)\end{array}$ & $\begin{array}{l}-0.175^{* * *} \\
(-30.52)\end{array}$ & $\begin{array}{l}-0.177 * * * \\
(-36.55)\end{array}$ \\
\hline $\log (\operatorname{Std} 3 R O A)$ & $\begin{array}{l}-0.215 * * * \\
(-3.69)\end{array}$ & $\begin{array}{l}0.217 * * * \\
(-3.30)\end{array}$ & $\begin{array}{l}-0.207 * * * \\
(-3.87)\end{array}$ & $\begin{array}{l}-0.040 \\
(-0.53)\end{array}$ & $\begin{array}{l}-0.045 \\
(-0.45)\end{array}$ & $\begin{array}{l}-0.108 \\
(-1.27)\end{array}$ & $\begin{array}{l}-0.174 * * * \\
(-3.63)\end{array}$ & $\begin{array}{l}-0.172 * * * \\
(-3.10)\end{array}$ & $\begin{array}{l}-0.182 * * * \\
(-3.98)\end{array}$ \\
\hline F_ccomp $* \%$ Excess & & & & & & & $\begin{array}{l}0.006 * * \\
(2.35)\end{array}$ & $\begin{array}{l}0.005 \\
(1.47)\end{array}$ & $\begin{array}{l}0.006 * * \\
(2.14)\end{array}$ \\
\hline Industry Indicators & Yes & Yes & Yes & Yes & Yes & Yes & Yes & Yes & Yes \\
\hline Year Indicators & Yes & Yes & Yes & Yes & Yes & Yes & Yes & Yes & Yes \\
\hline Adj R-Sq & 0.47 & 0.32 & 0.38 & 0.58 & 0.34 & 0.43 & 0.50 & 0.32 & 0.40 \\
\hline F value & $131.45 * * *$ & $70.96 * * *$ & $93.50 * * *$ & $115.68 * * *$ & $42.85^{* * * *}$ & $63.45 * * *$ & $221.58 * * *$ & $106.57 * * *$ & $145.84 * * *$ \\
\hline
\end{tabular}

$*$ is significant at $10 \%, * *$ is significant at $5 \%$, and $* * *$ is significant at $1 \%, t$-statistics are based on White's (1980) heteroskedasticity-adjusted standard errors. $R O A l(R O A 2)$ is the return on assets for the subsequent one (two) year(s) after compensation was awarded. AvgROA3 is the average return on assets over the subsequent three years from which compensation was awarded.

$\%$ Excess is equal to the natural logarithm of actual compensation less the natural logarithm of expected compensation. Log(Sale) is the natural logarithm of gross sales (in $\$$ mil) reduced by cash discounts, trade discounts, returned sales and allowances for which credit is given to customers. $B M V$ (book to market value) is measured as total common equity divided by market value (measured in millions of dollars). $\log (\operatorname{Std} 3 R O A)$ represent the natural $\log$ of the three year standard deviation of ROA. 